\title{
Sciendo
}

10.2478/topling-2020-0011

\section{Middle English occupational terms with Scandinavian word stems: Functional, semantic and chronological issues}

\author{
Oksana Dobrovolska* \\ Kyiv International University
}

\begin{abstract}
The article presents the results of a study of functional, semantic and chronological issues concerning Middle English occupational terms with Scandinavian word stems. The semantic group under investigation consists of 184 words, comprising $24.5 \%$ of the total number of loan-blends within the semantic group of Middle English occupational terms, and 8\% of the total 2,417 Middle English occupational terms. 97 loan-blends with Scandinavian word stems were revealed on the basis of proper names. They constitute 13\% of all Middle English occupational terms. a predominance of the function of identification and a very active usage with the aim of identifying people in medieval society prove loan-blends with Scandinavian word stems to be very popular. The data obtained in the study prove the very high level of popularity of Scandinavian borrowings in Middle English, as well as a prevalence of the names of artisans among all the semantic groups of the word stems. We noted an increase in the number of derivatives first attested in the 13th and the 14th centuries, whereas a decrease in the process of word formation on the basis of Scandinavian borrowings is noticed in the 15th century.
\end{abstract}

\section{Key words}

chronological stratification, common noun, lexical borrowing, loan-blend, occupational term, proper noun.

\section{Introduction}

The linguistic phenomenon of lexical borrowing is an important factor of language development and one of the key issues of the theory of the English language. As concerns the Middle English period, one of the most controversial problems lies in the etymological foundations of the language and the spheres of foreign-language influence, as well as the issues of Middle English word-building, in particular the structural patterns, time and rapidity of the process of word-building on the basis of borrowed words. a large number of scholars uphold the idea of the "mixed character" of the English language and treat borrowings as the main way of vocabulary enrichment (Baugh \& Cable, 1951; Bradley, 1924; Derocquigny, 1904; Emerson, 1921; Greenough \& Kittredge, 1920; Groom, 1934; Jespersen, 1912, 1922; Lounsbury, 1897; McKnight, 1956, 1969; Smith, 1912; Weekley, 1965), whereas some scholars (Amosova, 1956; Sekirin, 1955, 1964; El'darov, 1984) oppose them by putting forward the idea of wordbuilding as the prominent manner of English vocabulary development.

\footnotetext{
* Address for correspondence: Oksana Dobrovolska, Kyiv International University, Department of Germanic Languages and Translation, 49 Lvivska St., 03179 Kyiv, Ukraine. E-mail: oxanadobrovolska@ukr.net
} 


\section{Literature review}

Scandinavian lexical borrowings are related to the Viking invasions of the 8th century and settlement in different parts of the country, or were the result of peaceful contact between the English and the Scandinavians during the 12th century. The relationship between the two languages in the areas inhabited by the Danes is highlighted by scholars as "admissibility", rather than a relationship on the basis of accurate data (Sekirin, 1964, p. 92): it is impossible to establish the precise period of time when Scandinavian dialects existed in England, because for a long time until the Norman Conquest there were communities in which the Danish and the Norwegian languages were used and constantly renewed as a result of military raids and trade. Even in those areas where the English language predominated, there were also many settlers, who continued to speak their native language at least until 1100.

Scandinavian borrowings have been thoroughly studied on a chronological, lexical and semantic basis (Baugh \& Cable, 1951; Jespersen, 1912; Lindelöff, 1928; Potter, 1964; Serjeantson, 1935; Dance, 2003; Pons-Sanz, 2013) or presented alphabetically without classification (Greenough \& Kittredge, 1920, p. 61; Groom, 1934, p. 33; McKnight, 1969, p. 162). According to the chronology of their written attestation, they are divided into three periods: the first period - from 900 to 1016, which is characterized by the borrowing of terminology; the second period - from 1016 to 1150 (in the written record, there were 83 words found belonging to the commonly used vocabulary); the third period - from 1150 to 1350, when Scandinavian borrowings of a diverse nature in and large number were used in Middle English writings (Serjeantson, 1935, pp. 64-82).

In total, around 900 Scandinavian lexical borrowings were discovered (Sekirin, 196, p. 94). As for borrowings of the Old English period, they are associated with the daily life and social structure of the Scandinavians and are often of terminological character (Björkman, 1900-1902, pp. 5-6); borrowings of the Middle English period were of wide usage, i.e. they were among the commonly used vocabulary and did not designate new subjects and concepts (Sekirin, 1964, p. 99; Serjeantson, 1935, p. 65).

Due to the close affinity of the English and Scandinavian languages it is expedient to speak not of the contact among different languages in the era of the Scandinavian conquest, but about the interaction between the various dialect units of the English language in the process of regular communication between speakers; because of the regular identification of words as the English or Scandinavian variants of the same word, there was a constant interaction between them. It resulted in a third option, which was not related to a new concept by the English people, but was more convenient for adequate expression of thought and combined the features of both dialects (Smitnitskij, 1956, pp. 247-249).

However, not only the partial coincidence of the main vocabulary of the ancient Germanic languages and the commonality of their grammatical structure but also the existence of similar internal laws of language development (in particular semantic) determined the ease of the 'crossing' of the English language with the Scandinavian languages, as well as the victory of the English language and the development of a significant number of Scandinavisms (Yartseva, 2004, p. 51).

About 40 words of Scandinavian origin are attested in the medieval English written records. The reason for this insignificance is the enmity of relations and the lack of permanent contacts, although scholars noted that Old English literary works were written mainly in the West-Saxon dialect, i.e. the language of that part of England, where the Scandinavian influence was not significant (Baugh \& Cable, 1951, p. 116).

Most of the early Scandinavian borrowings entered the spoken language during the 9th-11th centuries; their penetration into English, apparently, ended in 1250, at least in the north and east of England, and some Scandinavian words appeared in the southern dialect much later. Numerous Scandinavisms were recorded in the written record of the 13th century coming from areas of not massive Scandinavian settlement; hence, it follows that the vocabulary of the literary English language was not based on Old English literature, but on the basis of the commonly spoken folk language (Sekirin, 1964, p. 95; Lindelöff, 1928, p. 56).

In the period of the formation of the English national literary language, one can speak only about the role of the northern dialects, which absorbed the bulk of Scandinavisms, as well as the interdialectal rather than inter-lingual ties in the 14th-15th centuries (Yartseva, 2004, p. 52), since most Scandinavism entered literary English through the northern dialects and became popular only during the period of the formation of the English national language on a mixed-dialect basis. 
In general, scholars determine the role of Scandinavisms in enriching the English vocabulary not on the basis of their abundance or significance, but due to their character and expression of vital concepts (Gal'perin \& Cherkasskaja, 1956, p. 135).

The issue of the time and rapidity of loan-blending in the Middle English language is the debatable issue of assimilation of lexical borrowings. Serjeantson (Serjeantson, 1935, p. 22) allows that foreign words once borrowed into the English language have always been freely connected with native suffixes. Sekirin confirms that the ability of lexical borrowings to become involved in the process of wordbuilding becomes possible only when these words have already expanded in a language and are already largely assimilated; the construction of derivatives with the help of native affixes testifies to the further assimilation of these words in the English language (Sekirin, 1955, pp. 83-84). Touching upon lexical assimilation of foreign language borrowings, Pedchenko noted the high degree of assimilation of Scandinavian nouns: having entered English and remaining in it, they served as the basis for creating new words in the most productive ways of English word-building (the process of word-building of new words occurred at the end of the Middle English and New English periods) (Pedchenko, 1956, p. 302).

A very valuable object of linguistic analysis elaborating the methodology of historical research is the lexical semantic group of occupational terms that make up a widely represented and constantly supplemented system of words with diverse structure, semantic peculiarities and long history. Occupational terms are in the focus of linguistic studies; their structure and functioning in Modern English are viewed in relation to cognitive study and that of onomasiology (Bernatskaia, 1995; Khalilova, 1975), as well as through the lens of their development (Liapkova, 2006; Shilova, 2006). Middle English nomina agentis have been studied as to their structural peculiarities (Kuznetsova 1984; Nikitina, 2005), especially in the aspect of onomasiology (Solonovich, 1986); numerous linguistic papers serve as the lexicographic sources of English historical lexicology and personal names study (Ekwall, 1947; Fransson, 1935; Thuresson, 1950). There is a need for a comprehensive disclosure of the issues of language evolution and language interference, as well as the issues of many aspects of the systematization of the Middle English vocabulary and functional assimilation of borrowings, i.e. on the basis of their acquisition of native usage and speech activity. Research of some functional, semantic and chronological issues of Middle English occupational terms has been provided from the aspect of language change (Dobrovolska, 2018).

As to the origins of the word stems of the loan-blends, they consist of Central French (31.5\%), Scandinavian (24.5\%), double Latin/French (20\%), Latin (12\%), Norman (7\%), Low Germanic (4\%) and Celtic (1\%) (Dobrovolska, 2018, p. 23).

In this paper we deal with the issues of the functioning of loan-blends with Scandinavian word stems as concerns the nominative function they fulfilled in the Middle English period, as well as the issues of their semantics and chronology.

\section{Research methods}

All the nominative units are divided into those that fulfil the function of classification (i.e. common nouns) and those that fulfil the function of identification (i.e. proper names); therefore we distinguish occupational terms in connection with these two kinds of nominative function which they fulfilled in the Middle English period. In terms of the functional differentiation of the Middle English loan-blends, the following general issues are in the focus of our research:

1) Etymological grouping of the Middle English loan-blends according to their motivational bases (amid functional varieties);

2) Semantic grouping of the Middle English loan-blends (amid functional varieties and etymological groups);

3) Chronological stratification of the dates of the first written records of the loan-blends, i.e. their first attestation in the time frame of the Middle English period.

Thus, the general object of our study is the system of Middle English loan-blends within the lexical semantic system of Middle English occupational terms, whereas several issues of their development (particularly the etymological composition of their motivational bases, semantic grouping of loan-blends and their functional differentiation, as well as the chronological stratification of their first written attestations) constitute the general subject of our research. 
We set forth the following particular tasks of our paper, which is devoted to the research of Middle English occupational terms with Scandinavian word stems and constitutes part of the more general study of Middle English loan-blends amid occupational terms:

1) Collect Middle English loan-blends denoting occupational terms from historical dictionaries;

2) Distribute the loan-blends into three groups as to the kinds of nominative function they perform, in particular: a) the group of occupational terms with the function of classification, namely common nouns; b) the group of occupational terms with the function of identification, namely proper names; and c) the group of occupational terms with both kinds of nominative function;

3) Fulfil a lexical semantic grouping of Middle English loan-blends (among lexical semantic subgroups and series of synonyms);

4) Stratify chronologically the dates of the first attestations of the Middle English loan-blends;

5) Give the observed phenomena absolute and relative quantitative characteristics and display the data of calculations in tables.

General procedure of our research consists of the following steps:

Step 1: Distribution of Middle English occupational terms among the groups of languages according to the origin of the borrowings, which were assimilated in the English language and served as the motivational basis of loan-blends (either the word stem in a simple derivative or a compound noun).

Middle English occupational terms are presented in the historical dictionaries (DBS, MED and NED) as common nouns or as proper names, particularly in the following ways:

1) At the end of the dictionary articles supplemented with the lexicographic markers of usage 'a surname', 'in names', 'in surnames', e.g. barker, berker 'a) a tanner; a member of the guild of tanners'1419 MED, b) in names; 'a tanner' 1402 NED (barken [ON; cp. Swed. barka] 'to tan (hides) with an infusion of bark' 1334 MED): Berker 1185, 1250, 1459, berkier 1193, Barkier 1203, Bercher 1212, Barker 1243, 1260, Barkere 1255, 1324, barker 1459, berker 1459;

2) As a word with the lexical meaning derived by lexicographers on the basis of personal names and usually supplemented with the lexicographic markers of usage, in particular 'as surnames', 'only as surnames', 'in surnames' (i.e. the term is only attested as a personal name, and not as a common noun): viz. *capel-man 'one who looks after horses' DBS (capel [ON; cp. OI kapall (ult. L caballus)] 'a horse or gelding; a warhorse, cart horse, riding horse, etc.' 1300 MED): Capelman 1327; *leyker 'player, actor' DBS (leiken [ON; cp. OI leika, OE lācan] 'to engage in a game or contest, sport; also, trifle; play (with sb. or sth.); take pleasure (in sth.); delight (to do sth.); play (a game with sb.)' 1200 MED): Laycar 1274, Leykere 1309, 1327; *galter 'a keeper of swine', as surname - MED, galt [ON; cp. OI göltr \& galti] 'a boar; also, a barrow'): Galter 1297, 1498; *knif-smith 'a cutler', only as surname - MED (kniff [LOE (<ON) cnïf \& ON; cp. OI kniffr] 'a knife; a dagger or sheath knife carried or worn on the person; a knife as a weapon [usually distinguished from sword]; an instrument for cutting or scraping made of material other than metal' 1200 MED): Knifsmith 1246-89, Cnyfsmith 1255, Knysmyt 1284, Knyfsmith 1284, Knyfsmith 1285, Knyfsmyth 1310, Knysmyt 1326, Knyfsmyth 1347; *lëd thekere 'a builder of lead roofs' - only as surname MED (lēd [OE lēad] 'lead, either the metal or the metallic ore', thacchere $(<$ thacchen [OE peccan \& ON: cp. OI pekja]) 'one who covers the roof or walls of a building with thatch or other material' $1350 \mathrm{MED}$, thache [OE pac, LOE (in place names) tace, tache \& OE paca \& $\mathrm{ON}$ (cp. OI pak)] 'sraw, reeds, or similar material used in covering a roof, thatch' $1343 \mathrm{MED}$ ): Ledtheker 1305; *lāthe-man 'worker at the barn(s)' DBS, in surnames - MED (lāthe [ON; cp. OI hlaða] 'a barn for livestock, grain, etc.; a granary; a storehouse' 1250 MED): Latheman 1278; *mader(er (in surnames - MED) 'dyer with or seller of madder' DBS (mader(e [OE maed(e)re, \& ON (cp. OI maðra)] 'the dye-stuff made from the roots of the plant Rubia tinctorum; a name given to dyes or dyestuffs other than Rubia tinctorum' 1425 MED): Maderere 1317, Madrer 1333;

3) As a word given without the definition of its lexical meaning but with the lexicographic markers of its usage (e.g. 'in surname(s)'), viz. *asshe-man, in surnames - MED (asshe [OE aesce, axe \& ON aska] 'ashes of combustible material' 1200 MED): Askeman 1203, Aisshman 1402; *spọn-man, in surnames - MED (spọnn [OE spōn; also cp. ON: cp. OI spānn, spōnn] 'a chip or slip of wood, a sliver, splinter' $1300 \mathrm{MED}$; 'a roofing shingle; a narrow slat of wood' $1310 \mathrm{MED}$; 'a spoon' 1350 MED): Sponman 1327; *bōle hẹrrd(e, in surnames - MED (bōle [ON, cp. OI boli \& OE *bula] 'a bull' 1200 MED, hệrd(e [OE] 'a herdsman'): Buleherte 1190, Bolherd 1320; *swein-man, in surnames - MED (swein [ON: cp. OI sveinn] 'a retainer, an attendant; a servant' 1200 MED): Swaynman 1266. 
Step 2: Distribution of Middle English loan-blends with Scandinavian word stems according to nominative function, particularly that of classification (as in common nouns) or identification (as in proper names) among the following functional groups:

a) loan-blends which were formed on the basis of assimilated lexical borrowings and were used both as common nouns and proper names (i.e. fulfilled two kinds of nominative function: identification and classification), e.g: bleikster(e 'one who bleaches cloth' 1400 MED (bleiken [ON; cp. OI bleikja (corresp. to OE blēecen)] 'to turn pale (as with fear)' $1330 \mathrm{MED}$ ): Bleckestere 1275; litester(e 'a dyer' 1380 MED, 1374 NED (liten [ON; cp. OI lita] 'to dye (cloth, garments), color, stain'1350 MED): Littestere 1235;

b) loan-blends which were formed on the basis of assimilated lexical borrowings and were only used as proper names (i.e. fulfilled only the function of identification). As far back as the Middle English period these loan-blends only functioned as proper names, as well as in the next periods of English language development; this means that our knowledge of their existence in Middle English is only based on the data of proper names (in particular by-names or family names). That is why we treat these loanblends to be reconstructed on the basis of Middle English proper names and mark them with *: e.g: *stithī (e makere MED (stithī(e [ON: cp. OI steði, (gen. \& in cpds.) steðja] 'an anvil' $1284 \mathrm{MED):}$ stethymaker 1413; *brod smith 'a maker of goads, ?a maker of nails' MED (brod [ON; cp. OI broddr] 'a sprout, a shoot; a pointed instrument, a goad; a nail' 1200 MED, smith ([OE smib] 'a blacksmith, an ironworker; a farrier; a worker in various metals' MED): bradsmyth 1455; *gadder '?a maker of goads, '?one who casts metal bars' MED ( $\operatorname{gad}(\mathrm{de}$ [ON; cp. OI gaddr] 'a sharp-pointed metal spike' 1400 MED; 'a sharp-pointed stick used for driving oxen etc.; a goad' 1300 MED; 'a metal bar or rod; an ingot of metal' 1250 MED; 'a metal rod used for measuring land' 1440 MED): Gadder 1285, 1324;

c) loan-blends which were formed on the basis of assimilated lexical borrowings and were only used as common nouns (i.e. fulfilled only the function of classification), e.g: leg makere 'a maker of artificial legs' (1500 MED) (leg [ON; cp.OI leggr] 'an artificial leg' 1500 MED); silke makere 'one who works with silk' $1500 \mathrm{MED}$ (silk(e [OE seoluc, seolc, sioloc; also cp. ON: cp. OI silki] 'silken cloth, silk; silken clothing; also, a silken garment' 1200 MED; 'silk fiber or thread; silk embroidery' 1300 MED).

Step 3: Distribution of Middle English loan-blends with Scandinavian word stems into semantic subgroups and rows of synonyms (here we consider the lexical semantic variants of the word, thus each of them is put in a corresponding semantic subgroup or particular row of synonyms, i.e. a word (either the common noun or proper name) might be mentioned several times in our semantic classification). It is worth mentioning that the basic source for our study of the lexical semantic variants of the words is the Middle English Dictionary (MED) - we study all the functional representations of the words (i.e. the common nouns and the proper names); then, in addition, we compare these data with those given in the Oxford English Dictionary (NED), and only if they differ (in their vocabulary definitions or in the time of their first attestation) we necessarily take them into consideration; finally, in the Dictionary of British surnames (DBS), we study the origin of Middle English surnames and their interpretation on the basis of the occupational terms, as well as the examples and dates as compared with the MED and NED.

Step 4: Stratification of the dates of the first written records of the Middle English loan-blends with Scandinavian word stems within the centuries of the Middle English period;

Step 5: Comparative characteristics of the observed phenomena in absolute and relative quantitative numbers and representation of these data in tables.

\section{Results and discussion}

According to our calculations, the total number of Middle English occupational terms is 2,417 (including 2,015 personal names, in particular surnames, represented in their 7,429 spelling variants in 10,204 examples of usage); among them, 755 Middle English occupational terms were formed on the basis of lexical borrowings and were loan-blends or hybridisms.

As to the kind of nominative function the loan-blends fulfilled in the Middle English period, we distributed them into the following three groups:

1) 213 loan-blends ( $28 \%$ of the total number of Middle English loan-blends) fulfilled two kinds of nominative function, namely that of classification and identification, i.e. they were used both as common nouns and as proper names (in the historical lexicography, the latter are recorded 1,285 times in their 928 phonographic variants); 
2) 402 loan-blends (53\% of the total number of Middle English loan-blends) only fulfilled the function of identification as proper names in their 761 phonographic variants that were used 904 times in historical lexicographic sources;

3) 140 loan-blends (19\% of the total number of Middle English loan-blends) only fulfilled the function of classification as common nouns in the Middle English period (Dobrovolska, 2018, p. 3).

In total, 184 of the Middle English loan-blends have Scandinvian word stems (comprising 24.5\% of all the Middle English hybridisms). We distributed them into three groups based on the kinds of nominative function they performed in the Middle English period: Group 1 - occupational terms used as proper names with the function of identification; Group 2 - occupational terms used with both kinds of nominative function; Group 3 - occupational terms used as common nouns with the function of classification.

Then, we fulfil the lexical semantic distribution of these functional groups of Middle English loanblends into lexical semantic subgroups and semantic rows of synonyms as follows.

\subsection{Semantic grouping of Middle English loan-blends which fulfil the functions of classification and identification}

\subsubsection{Semantic subgroup of the names of artisans}

\subsubsection{Names of textile workers}

a) names of weavers and spinners are the following: Selkwimman 1334, Silkwoman 1368, silkwoman 1428 (silk(e womman 'a woman who spins or sews silk, a seamstress' 1440 MED, 'a woman engaged in the manufacture, use or sale of silk' 1440 NED) (silk(e [OE seoluc, seolc, sioloc; also cp. ON: cp. OI silki] 'silken cloth, silk; silken clothing; also, a silken garment; silk fiber or thread; silk embroidery' MED);

b) names of dyers are the following: Bleckestere 1275, Blekestere 1281, Bleykster 1286, Blekstere 1287, Blaykster 1327, Bleykestere 1329, Blaikester 1332, Blikester 1332 (bleikster(e 'one who bleaches cloth' 1400 MED; bleiken [ON; cp. OI bleikja (corresp. to OE blöecen)] 'to turn pale (as with fear); to make (sb.) turn pale'); Littestere 1235, litestere 1279, Litster 1286, 1327, 1325, Lister 1292, Letstere 1305, Littester 1316, 1392, Lister 1325, Lyster 1327, Litester 1327, Listere 1327, 1338, lestere 1327, Letestere 1332, licstere 1345 , litster 1379, 1390, 1443-4, littester 1402, Littyster 1424, littyster 1424, lytester 1425 , lytsters 1428, lyttester 1431-2, littester 1446, lytster 1459, Littster 1438-9, Litstre 1472 (litester(e 'a dyer' 1380 MED, 1374 NED; liten [ON; cp. OI lita] 'to dye (cloth, garments), color, stain' MED).

\subsubsection{Names of tailors and sewers}

The names of tailors and sewers are the following: Hattere 1212, 1240, 1262, 1268, 1296, 1316, 1332, 1354, hattere 1225, Hettere 1280, 1296, Hatter 1281, 1465-6 (hatter(e 'a maker or seller of hats; usually as surname' MED, 'a maker of or dealer in hats' $1389 \mathrm{NED}$; hat [OE hat \& ON; cp. OI höttr] 'an outer head covering (often worn over a hood or a cap), a hat'); Selkwimman 1334, Silkwoman 1368, silkwoman 1428 (silk(e womman 'a woman who spins or sews silk, a seamstress' 1440 MED, 'a woman engaged in the manufacture, use or sale of silk' 1440 NED) (silk(e [OE seoluc, seolc, sioloc; also cp. ON: cp. OI silki] 'silken cloth, silk; silken clothing; also, a silken garment; silk fiber or thread; silk embroidery' MED).

\subsubsection{Names of skin-processing workers}

a) names of skinners are the following: Berker 1185, 1250, 1459, berkier 1193, Barkier 1203, Bercher 1212, Barker 1243, 1260, Barkere 1255, 1324, barker 1459, berker 1459 (barker, berker 'a tanner' 1402 NED; 'a tanner; a member of the guild of tanners'1419 MED; barken [ON; cp. Swed. barka] 'to tan (hides) with an infusion of bark'); Scynnere 1255, Sckinir 1257, Skynnere 1263, Skenner 1264, Skinnere 1269, Scinner 1279, Skinere 1285, Schinnere 1296, Schinner 1305, Skynnersone 1332, Skynnar 1332, skinner 1351-2, Skynere 1382, Schynnere 1406, Skynner 1429 (skinnere 'one who prepares or sells animal skins, a furrier, skinner' 1325 MED, 'one whose work or business is concerned with 
the preparation of skins for commercial purposes' 1398 NED; skin [ON (cp. OI skinn) \& OE scinn (from $\mathrm{ON})$ ] the prepared skin of an animal, leather; also, a piece of leather; also, a garment made of leather');

b) names of the artisans engaged in sewing of leather goods are the following: Glouere 1250, 1278, Glowere 1295, Glover 1308, Glovere 1313, Glover 1327, Glouare 1327, glouer 1355, Glouer 1413 (glōver 'one who makes or sells gloves; a member of a glovers' guild' $1364 \mathrm{MED}, 1400 \mathrm{NED}$; glōve [OE glōf \& ON; cp. OI gloffi] 'a glove; one of a pair of gloves; a glove or gauntlet used for armor; one of a pair of gauntlets').

\subsubsection{Names of artisans engaged in metal ironmongery}

a) names of blacksmiths are the following: Smythyman 1308, 1309 (smithi $\sim$ man 'a worker in a smithy' $1350 \mathrm{MED}$, 'an iron-smith' $1400 \mathrm{NED}$, smithī [ON: cp. OI smiðja] 'a blacksmith's shop, smithy, forge');

b) names of workers who make household utensils, tools, handicrafts are the following: Haruer 1255, Harewere 1275, Harwere 1327, 1338, Harower 1379 (harwere 'a maker of harrows' 1475 MED, 'a harrow-maker' 1483 NED, harwe [OE * hearwa < OE hyrwan 'to abuse, ill-treat, etc.'; prob. OI herfi 'harrow' \& harfr, Dan. Swed. harv, Norw. dial. horv] 'a harrow for cultivating land, a drag'); Plochewrychte 1269, Plowricht 1270, Plowritte 1279, Plogwryth 1285, Ploghwright 1297, Plowryth 1301, Ploghwrith 1309, Ploughwrighte 1316, Plouwricte 1332, Plouhwrihte 1334, Plowrihte 1337, Plowrighe 1345, Plowryght 1412 (plǒugh-wrighte 'a maker of plows, plowwright 1440 MED, plǒngh [LOE plōg, plōh (from ON) \& ON; cp. OI plōgr, Swed. plog, Dan. plov. As an element in names, plough is most freq. in area of the Danelaw]);

c) names of gunsmiths are the following: Aruesmyth 1278, Arrowsmyth 1315, Arwesmyth 1324, Arsmith (arwe smith MED, 'a maker of iron arrow-heads' 1400 NED, arwe [OE ar(e)wan; cp. OI ör, örvar] 'an arrow'); Gonner 1345-8, Gunner 1423 (gǒnner 'maker of cannon or of small firearms, a gunsmith' 1437 MED, gǒnne [prob. ON; cp. OI gunnr 'battle'] 'a siege engine that casts missiles; ballista, mangonel, trebuchet; also, a ram; a cannon'); Gunmaker 1371, Gonmaker 1385, 1385-6, gunne maker 1456-8 (gǒnne maker 'one who makes cannon or small firearms, a gunsmith' 1156 MED);

d) names of masters of coining, forging and quarrying of silver and gold are the following: Cliper 1300, 1327 (clipper 'one who clips coins' $1338 \mathrm{MED}$, clippen [ON; cp. OI klippa] 'to clip or mutilate (a coin); to shape or engrave (dies used in minting money)'.

\subsubsection{Names of artisans involved in woodworking and wooden products manufacturing}

Names of artisans involved in woodworking and wooden products manufacturing are the following: Carteworghte 1269, Cartwereste 1275, Cartewrychgte 1292, Cartwreute 1294, Cartewricht 1308, Cartwriht 1317, Cart Wrygthe 1327, Cartwrigte 1327, Cartewrighte 1327, Cartwryth 1327, Cartwhryt 1327, Cartewryght 1348, 1363 (cart wright 'one who makes or repairs carts or wagons' 1425 MED, cart [OE \& ON; cp. WS crat \& OI kartr] 'a cart, a wagon; a cartload; a chariot, a war chariot, the chariot of the sun; a coach or carriage'); Berther 1301, Beerdere 1436 (birdere 'a carpenter who covers the frame of a ship with boards or planks' 1338 MED, b̆̈rd(e [ OI byrði 'side of a ship'; OE gebyrd(ed 'clavatum'] 'a fringe or stripe'); Sceppere 1221, Skeppere 1281, skeppere 1287-8, sceppere 1296-7, Skepher 1327, skepper 1457 (skeppēr(e 'a basket weaver, basketmaker' 1449 MED; skepper (scepper) 'a maker of skep' 1499 NED); Skepmakere 1310 (skep(pe makere 1440 MED, skep(pe [ON: cp. OI skeppa \& OE sceppe (from ON); cp. AL skeppa, scheppa, skippa, scippa \& AF eskeppe, esc(h)eppe] 'a basket for grain, malt, coal, alms, etc.' 1440 MED); Lesponere 1179, Sponere 1221, 1254, 1265, Sponer 1306, 1327, 1331, 1346 (spọner(e 'one who makes shingles or spoons' $1390 \mathrm{MED}$, 'one who makes spoons' 1515 NED, spọnn [OE spōn; also cp. ON: cp. OI spānn, spōnn] 'a chip or slip of wood, a sliver, splinter; a roofing shingle; a narrow slat of wood; a spoon'); Sponemaker 1370, spoonemaker 1490 (spộn makere 'one who makes roof shingles or spoons' 1429-30 MED; spọ̄n [OE spōn; also cp. ON: cp. OI spānn, spōnn] 'a chip or slip of wood, a sliver, splinter; a roofing shingle; a narrow slat of wood; a spoon'). 


\subsubsection{Names of the construction workers}

a) names of builders are the following: Biggere 1307, Bygor 1321 (bigger(e 'one who constructs houses, builder' $1400 \mathrm{MED}$, 'a builder' $1440 \mathrm{NED}$, biggen [ON; cp. OI byggja] 'to build (a house, a bridge, etc.)');

b) names of roofers are the following:: Hulyere 1310, 1332 (hilere 'a roofer, a tiler' 1467 MED, hilen [ON; cp. OI hylja, ?OE *hyllan] 'to put roof on (sth.), roff'); Thecker 1199, Theccher 1251, 1333, Thechare 1273, 1327, Theker(e) 1273, 1297, Thacchere 1275, 1303, 1339, Tecchere 1277, thacherer 1286, Thecetere 1311, Thatcher 1312, 1327, Thaker 1316, 3acheare 1321-2, thekker' 1327, Thecchare 1327, Thecchar 1327, Thechar 1327, Thatchere 1327, Thecher 1327, Thechere 1327; Theckere 1332, Thachar 1332, Thakker 1336, 1466, Thakkere 1339, 1432, Thaccher 1364, Thaichere 1401, Thecchere 1408 (thaccher $(e$ 'one who covers the roof or walls of a building with thatch or other material' $1312 \mathrm{MED}$, 'one who thatches; esp. one whose business it is to thatch houses, corn or hay ricks, etc.' 1440 NED, thacchen [OE peccan \& ON: cp. OI pekja] 'to cover the roof of a building with thatch or other material; cover the roof of (a building or part of a building) with lead, tiles, etc.; also, cover (a wall) with thatch'); Thakestere 1295, 1329, 1364, Thakster 1332, Thakester 1332, Thaxther 1332, Thaxtere 1355, Thakstere 1381, Thaxster 1400 (thakester(e 'one who covers the roof or walls of a building with thatch or other material' 1440 MED, 'thacker' 1440 NED);

c) names of lime-burners and plasterers are the following: limbernere 1226, Limbarner 1240, Lymbrennere 1240, limberner 1311-12, Lumbernare 1313, Lymbrinner 1327, Lymberner 1365-7, lymebrenner 1440, 1470, lymburner 1443-6 (lim - brennere 'one who calcines limestone' 1432 MED, 'one whose occupation it is to make lime by burning limestone' 1329 NED, lim [OE] 'lime produced by calcining limestone');

d) names of makers of brick-makers are the following: Teobaldus filius Bernerii 1086, Berner 115060, 1219, berner 1190-1, Bernier 1190-1, Bernerus 1211, Brenner 1280, 1327, Brynner 1327 (brennere 'one who makes bricks, etc. by using fire' MED, 'one who prepares or produces by burning, chiefly in comb., as brick-, charcoal-, lime-burner' 1463 NED, brennen [ON, cp. OI brenna] 'to treat (sth.) with fire or heat: to calcine (limestone), to bake (tiles)').

\subsubsection{Names of food-processing workers (names of butchers)}

Names of food-processing workers (names of butchers) are the following: slaughterman 1446-7 (slaughter-man 'a butcher' $1389 \mathrm{MED}$, slaughter [ON *slahtr: cp. OI slätr 'butcher's meat'] 'the killing of a person, murder, assassination, homicide').

\subsubsection{Semantic subgroup of names of graziers, farmers and gardeners}

\subsubsection{Names of graziers}

a) names of herdsmen are the following: Mukere 1229, Muker 1276, Moker 1296, 1327, Moukor 1332 (mukker '?one who cleans stables, a manure hauler' 1475 MED, mukken (<muk n. [ON; cp. OI myki 'dung' \& Norw. dial. mukka 'a heap'] 'animal or human excrement; dung; manure; also, dirt, filth; sewage; putrescence'; also cp. OI moka v.) 'to spread manure; fertilize (plants, land) with manure; prepare land for planting; also, remove dung (from a place), haul manure; to dig in the ground');

b) names of livestock breeders of cattle are the following: Geldehyrd 1284, Geildehirde 1298, Geldehirde 1317, Geldhurd 1319 (geldherd 'one who tended the 'geld' cattle' 1317 NED, geld(e-hirde 'a herdsman who tends to the gelded cattle' MED, geld [ON; cp. OI geldr] geld hors 'a gelding'; geld gris, geld hogge 'a barrow'; geld ram, geld $\sim$ shep 'a wether', gelding n. [ON; cp. OI geldingr] 'a gelded horse, gelding', hẹrrd(e [OE] 'a herdsman'); noutehird 1296, Nouthirde 1301, 1328, Nauthird 1309, Nautherde 1316, Noutehirde 1327-30, nouthird 1327, Noutherd 1340 (nǒut-hẹrrd(e 'a cowherd' 1450 MED, 1330 NED, nǒut(e [ON; cp. OI naut] 'an ox, a bull'); 
c) names of shepherds are the following: Cliper 1300, 1327 (clipper 'a sheepshearer' 1382 MED, clippen [ON; cp. OI klippa] 'cut hair; to shear (sheep); to clip or mutilate (a coin); to shape or engrave (dies used in minting money)';

\subsubsection{Names of farmers}

Names of farmers are the following: Haruer 1255, Harewere 1275, Harwere 1327, 1338, Harower 1379 (harwere 'one who cultivates with a harrow' $1500 \mathrm{MED}$, harwe [OE *hearwa < OE hyrwan 'to abuse, ill-treat, etc.'; prob. OI herfi 'harrow' \& harfr Dan. Swed. harv, Norw. dial. horv] 'a harrow for cultivating land, a drag'); Hauerman 1332 (hä̌ver man 'one who raises or sells oats' 1306 MED, h̆̈̌ver n [prob. ON] 'the cereal grain, oats'); Husebond 1176, 1231, Husebonde 1235-52, Husbonde 1275, 1419, Hosbonde 1279, 1327, Husebond 1294, Huseband 1301, Hosebunde 1307, Husseband 1332, Hosebonde 1341, Hosebond 1377, Husbond 1472 (hǒus-bŏnd(e [LOE hūs-bōnda, -bunda, from $\mathrm{ON}$ ] 'a tiller of the soil, husbandman, farmer; also, a rustic' $1250 \mathrm{MED}$, 'one who tills and cultivates the soil; a cultivator, tiller, farmer, husbandman. In early northern use, app. applied spec. to a manorial tenant, the villanus or villein of other districts' 1220 NED); husebundeman 1225-32, husbondman 1435, 1475, husbandman 1413, 1444, Husbandman 1495 (hus-bönd-man 'a farmer, tiller of the soil, owner of a farm; also, a rustic' 1384 MED); Mukere 1229, Muker 1276, Moker 1296, 1327, Moukor 1332 (mukker '?a gardener, one who prepares soil for planting' $1475 \mathrm{MED}$, mukken (< muk n. [ON; cp. OI myki 'dung' \& Norw. dial. mukka 'a heap'] 'animal or human excrement; dung; manure; also, dirt, filth; sewage; putrescence'; also cp. OI moka v.) 'to spread manure; fertilize (plants, land) with manure; prepare land for planting; also, remove dung (from a place), haul manure; to dig in the ground'); Pleueman 1223, Plouman 1223, 1260, 1275, Ploman 1255, 1327, Plouman 1275, ploghman 1275, Ploghman 1276, 1327, Ploxhman 1301, Plougman 1316-17, Plogman 1332, Plowman 1345 (plǒugh-man 'a plowman, farmer' $1263 \mathrm{MED}$, 'a man who follows and guides the plough; often used generically for a farm-labourer or rustic' $1271 \mathrm{NED}$; plǒugh [LOE plōg, plōh (from ON) \& ON; cp. OI plögr, Swed. plog, Dan. plov] 'a plow');

\subsubsection{Names of gardeners}

Names of gardeners are the following: Rakyere 1327, Rakyere 1331, rakyere 1384, Rakyer 1404-5, Rakere 1422 (rāker(e '?a gardener' $1440 \mathrm{MED}$, rāken [ON: cp. OI raka] 'to rake away rubbish; rake (a field, grass)'; rāken [ON: cp. OI raka] 'to rake away rubbish; rake (a field, grass)'.

\subsubsection{Semantic subgroup of names of sailors}

Names of sailors are the folloing: Batsuen 1055, Batswegen 1050-71, Batsuein 1190, Botsweyn 1319, 1327, 1332 (bōt $\sim$ swein [late OE bátswezen] 'a minor officer on a ship, a boatswain; prob. also, a sailor' $1304 \mathrm{MED}$, 'an officer in a ship who has charge of the sails, rigging, etc., and whose duty it is to summon the men to their duties with a whistle' $1450 \mathrm{NED}$ ); bōt [OE bāt] 'a boat'; swein [ON: cp. OI sveinn] 'an attendant upon a knight, a squire; a soldier below the rank of knight; a retainer, an attendant; a servant; a man, young man, boy' MED); Cokeswayne 1327 (cokswain 'an officer in charge of a cockboat and its crew, coxswain' $1463 \mathrm{MED}$; cok [AF coque (corresp. to CF coche)] 'a ship's boat, cockboat; also = cogge 1319 MED; swein [ON: cp. OI sveinn] 'an attendant upon a knight, a squire; a soldier below the rank of knight; a retainer, an attendant; a servant; a man, young man, boy' MED).

\subsubsection{Semantic subgroup of names of intellectuals}

\subsubsection{Names of writers and translators}

Names of translators are the following: Drahere 1327, Drawere 1332, Drawer 1390 (drauere 'a translator' 1410 MED, drauen [OE dragan, cp. OI draga]).

\subsubsection{Names of physicians}

Names of physicians are the following: Cliper 1300, 1327 (clipper 'a barber' 1425 MED, clippen [ON; cp. OI klippa] 'cut hair'). 


\subsubsection{Semantic subgroup of names of artists and entertainers}

\subsubsection{Names of artists}

Names of artists are the following: Caruier 1203, Carver 1209, Kerver 1275, 1277, Keruere 1327, Keruer 1327, kervere 1368, Kervor 1415, Kervoure 1442-3, Kyrvieur 1450-51, Kervour 1460-1, carver 1469 Carver 1471 (kervere 'a person whose occupation involves various kinds of cutting: one who forms images or ornaments by cutting in wood or stone; a wood-carver, sculptor, etc.' 1376 MED, carver 'one who carves wood, ivory, stone, etc.; a sculptor: most frequently (when not otherwise qualified) applied to one who carves in wood' 1386 NED, kerven [OE ceorfan; ON; cp. Norw. karve, Swed. karfva] 'to cut or pierce, make a cut or incision'); Cliper 1300, 1327 (clipper 'one who shapes or engraves dies used for minting coin' $1469 \mathrm{MED}$, clippen [ON; cp. OI klippa] 'to clip or mutilate (a coin); to shape or engrave (dies used in minting money)';

\subsubsection{Names of entertainers}

Names of entertainers are the following: Skippere 1320 (skipper(e 'one who skips or dances' 1250 MED, skippen [?ON: cp. OSwed. skuppa, Swed. dial. skimpa] 'to jump, leap, spring; skip or jump in play, caper' 1325 MED).

\subsubsection{Semantic subgroup of names of officials}

\subsubsection{Names of lawyers and officers}

Names of lawyers and officers are the following: Lager 1327, Lawyer 1336 (lauier(e 'one skilled in the law; an advocate, a lawyer' 1387 MED); Heiuuard, Haiuuard 1095, Haiward 1166, Heiward 1176, heiward 1200, Hawyard 1252, Heyward 1275, hayward 1294, Hayword 1325, Haward 1331, Haywarte 1408 (hei-ward 'an officer of a manor, village, or religious establishment, charged with maintaining hedges and enclosures, with keeping cattle on the common, with protecting grain from trespass and theft, with supervising the harvest of grain, etc.; an agricultural overseer, field keeper, hayward' 1300 MED; hei [OE; also cp. OI hey] 'grass cut or mowed and cured (usually as feed for livestock), hay; also, growing grass'; ward ([OE weard] 'a guard, sentinel; a guardian').

\subsubsection{Names of messengers}

Names of messengers are the following: Rennere 1134, 1319, 1340, 1369, 1393 (renner(e 'a messenger; ?an advance guard, scout' $1382 \mathrm{MED}$, 'one who carries messages on foot or horse-back; a messenger, courier, errand-bearer; a scout' 1300 NED, rennen [OE rinnan \& ON: cp. OI renna, rinna] MED).

\subsubsection{Names of watchmen}

Names of watchmen are the following: Waker 1327 (wäker(e 'one who keeps watch or is vigilant, a watcher; a watchman; a guard, custodian; also, a sentinel' 1382 MED, wāken [OE *wacan, also cp. ON: cp. OI vaka \& vekja] 'to remain awake in a custodial, protective, or supervisory capacity; to stand guard, serve as a sentry or watchman'); Wakeman 1180, 1200, 1225-50, 1238, 1262, 1287, 1301, 1327 (wāke-man 'a watchman, sentinel, protector' 1200 MED; 'one who remains awake or abroad at night; specif., a town guard or night watchman; also, a municipal officer responsible for nighttime security and the playing of instruments' 1350 MED, 'a watchman' 1200 NED, waken v. [OE *wacan, also cp. ON: cp. OI vaka \& vekja] 'to remain awake in a custodial, protective, or supervisory capacity; to stand guard, serve as a sentry or watchman'; wake n. [OE wacu \& wacen; also cp. ON: cp. OI vaka] 'one of the several periods into which the night and nighttime guard duty were formerly divided').

\subsubsection{Names of executioners}

Names of executioners are the following: slaughterman 1446-7 (slaughter-man 'an executioner' 1375 MED, slaughter [ON *slahtr: cp. OI slätr 'butcher's meat'] 'the killing of a person, murder, assassination, homicide'). 


\subsubsection{Semantic subgroup of names of domestic servants}

\subsubsection{Names of courtiers, employees of estates and servants}

Names of courtiers, employees of estates and servants are the following: Caruier 1203, Carver 1209, Kerver 1275, 1277, Keruere 1327, Keruer 1327, kervere 1368, Kervor 1415, Kervoure 1442-3, Kyrvieur 1450-51, Kervour 1460-1, carver 1469, Carver 1471 (kervere 'one who attends a superior at the table by cutting up his meat and serving food, one who waits table' 1395 MED; carver 'one who carves at table' 1432-50 NED, kerven [OE ceorfan; ON; cp. Norw. karve, Swed. karfva] 'to cut or pierce, make a cut or incision'); foer 1190, Fuer 1219, Four 1219, Fower 1279 (fouer 'a cleaner of privies, etc.' 1411 MED; 'a one who, or that which, cleanses or purifies' 1440 MED, fouen [cp. OI fäga] 'to clean out (something), to clear (a ditch)'); Gangfurmer 1293-4 (gă̈ng fermour 'a cleaner of privies' 1400 MED, găng [OE gang, gong \& ON (cp. OI gangr)]) 'a privy; a road, path, way'; viz. ğăng fouer 'a cleaner of privies' 1475 MED, găng man 'a cleaner of privies' 1200 MED); Rakyere 1327, Rakyere 1331, rakyere 1384, Rakyer 1404-5, Rakere 1422 (rāker(e 'a street cleaner, scavenger, refuse collector' 1357 MED, rāken [ON: cp. OI raka] 'to rake away rubbish; rake (a field, grass)').

\subsubsection{Names of carriers, loaders and carters}

Names of carriers, loaders and carters are the following: Drahere 1327, Drawere 1332, Drawer 1390 (drauere 'one who pulls, drags, or transports something', drauen [OE dragan, cp. OI draga]) 1450 MED; Feryere 1279, 1281, 1392, Feryer 1281, 1319, feryere 1285, Feryour 1390, ferier 1324 (ferier(e 'one who keeps a ferry, a ferryman' $1440 \mathrm{MED}$, 'one who keeps or looks after a ferry' 1440 NED, ferien v. [OE ferian, ferode] 'to transport, carry, convey, or lead; also, to carry off, lead away; to transport in a boat, to ferry; ferie n. [cp. ME ferien 'to transport' \& OI ferja 'a ferry'] 'a place where passengers, goods, etc., are carried by boat over a narrow body of water; also, the boats and other equipment used in ferrying; a ferry-boat'); ferriman 1192, Feriman 1247, 1297, Phariman 1265, Fermon 1332, Feremone 1354, ferriman 1414 (feri-man 'one who owns or operates a ferry' 1464 MED, 'one who keeps or looks after a ferry' 1464 NED, ferie [cp. ME ferien 'to transport' \& OI ferja 'a ferry'] 'a place where passengers, goods, etc., are carried by boat over a narrow body of water; also, the boats and other equipment used in ferrying; a ferry-boat'); Wyndrawer 1294, Wyndrawere 1319, wyndragher 1335-6, Wyndrawer 1373, Wyndrawer 1381, wyne drawer 1450, wynedrawer 1468 (wine-drawer 'one involved in the transporting of wine, a carrier of wine' $1335 \mathrm{MED}$, drauere 'one who pulls, drags, or transports something' ( $<$ win $[\mathrm{OE}<\mathrm{L}]$, OF vin, AF vine \& OI vin); drauere 'one who pulls, drags, or transports something' < drauen [OE dragan, cp. OI draga]).

\subsubsection{Semantic subgroup of names of merchants}

Names of merchants are the following: Bagger 1246, Baggere 1297, Bagere 1308, Baghiar 1313, Badger 1324, 1346, Baghar' 1329, Badgare 1332, Baggare 1333, Baghere 1348 (bagger, bağğer 'a retailer or hawker in grain, a badger' 1467-8 MED, 'one who buys corn and other commodities and carries them elsewhere to sell; an itinerant dealer who acts as a middleman between producer (farmer, fisherman, etc.) and consumer; a cadger, hawker, or hukster' $1500 \mathrm{NED}$, bagge [ON, cp. OI baggi; cp. also OF bague (from Gmc.) \& AL bag $(g) a]$ 'a bag or sack, traveling bag, wallet, satchel, pouch'); Hattere 1212, 1240, 1262, 1268, 1296, 1316, 1332, 1354, hattere 1225, Hettere 1280, 1296, Hatter 1281, 1465-6 (hatter(e 'a maker or seller of hats; usually as surname' MED, 'a maker of or dealer in hats' 1389 NED; hat [OE hat \& ON; cp. OI höttr] 'an outer head covering (often worn over a hood or a cap), a hat'); Ismangere 1164-5, 1165-72, 1249, iremongere 1200, Hyrnmangere 1213, Ironmangere 1221, Iremangere 1247, Ismongere 1248, 1310, Yernmonger 1255, Irmongere 1255, Hyrmonger 1279 , Irinmongere 1279, Irnemongere 1279, 1339, 3ernmogare 1293-4, Ironmongere 1294, Hismongere 1296, hirnmonger 1298, Irremonger 1305, Irenmonger 1305, yremongere 1327, Yerenmanger 1327, Ernmongere 1327, Yernemanger 1332, Ismongar 1332, Irmonger 1340, 1404-5, ismongere 1349, irenmanger 1379, irenmonger 1415, yremongere 1432, iremonger 1434-5, Iremonger 1442 (ìrenmōngere 'a dealer or merchant in ironware' 1363-4 MED, 'a dealer in ironware; a hardware merchant' 1343 NED, ìren (is) [OE ìren \& isern, ìsen], mōnger(e [OE mangere] 'a merchant, tradesman, dealer'); Ripier 1279, ripiere 1384, rypier 1438, Ripper 1430, repyer 1450, rypyer 1450, Riper 1451 (ripier(e 'one who carries fish inland for sale' 1384 MED, 1513 NED, rip(pe [ON: cp. OI hrip] 'a basket for 
fish'); Selkwimman 1334, Silkwoman 1368, silkwoman 1428 (silk(e womman 'a woman who spins or sews silk, a seamstress' 1440 MED, 'a woman engaged in the manufacture, use or sale of silk' 1440 NED) (silk(e [OE seoluc, seolc, sioloc; also cp. ON: cp. OI silki] 'silken cloth, silk; silken clothing; also, a silken garment; silk fiber or thread; silk embroidery' MED); Scynnere 1255, Sckinir 1257, Skynnere 1263, Skenner 1264, Skinnere 1269, Scinner 1279, Skinere 1285, Schinnere 1296, Schinner 1305, Skynnersone 1332, Skynnar 1332, skinner 1351-2, Skynere 1382, Schynnere 1406, Skynner 1429 (skinnere 'one who prepares or sells animal skins, a furrier, skinner' 1325 MED, 'one whose work or business is concerned with the preparation of skins for commercial purposes' 1398 NED; skin [ON (cp. OI skinn) \& OE scinn (from ON)] the prepared skin of an animal, leather; also, a piece of leather; also, a garment made of leather').

Table 1. Semantic subgroups of the Middle English loan-blends with both the functions of lassification and identification

\begin{tabular}{|c|c|c|c|c|}
\hline \multirow{2}{*}{$\begin{array}{l}\text { Semantic } \\
\text { subgroups } \\
\text { Artisans }\end{array}$} & \multirow{2}{*}{$\begin{array}{l}\text { Lines of synonyms } \\
\text { textile workers: bleikstere, litestere, silke womman }\end{array}$} & \multicolumn{2}{|c|}{ Amount } & \multirow{2}{*}{$\begin{array}{c}\text { Rate } \\
(\%) \\
42\end{array}$} \\
\hline & & 3 & 28 & \\
\hline & tailors and sewers: hattere, silke womman & 2 & & \\
\hline & skin-processing workers: barker, glọver, skinnere & 3 & & \\
\hline & $\begin{array}{l}\text { metal workers: arwe smith, clipper, gǒnner, gǒnne maker, } \\
\text { harwere, plǒugh wrighte, smithī-man }\end{array}$ & 7 & & \\
\hline & $\begin{array}{l}\text { wood-processing workers: birdere, cart wright, skeppě̄re, } \\
\text { skep(pe makere, spōn makere, spōnere }\end{array}$ & 6 & & \\
\hline & $\begin{array}{l}\text { construction workers: biggere, brennere, hilere, } \\
\text { limm brennere, thacchere, thakestere }\end{array}$ & 6 & & \\
\hline & food-processing workers: slaughter-man & 1 & & \\
\hline \multirow{3}{*}{$\begin{array}{l}\text { Graziers, } \\
\text { farmers, } \\
\text { gardeners }\end{array}$} & graziers: clipper, geld herd, mukker, nǒut hẹrd(e & 4 & 11 & 17 \\
\hline & $\begin{array}{l}\text { farmers: harwere, hă̄ver-man, hǒus-bönd(e, hus-bŏ̄nd-man, } \\
\text { mukker, plǒugh-man }\end{array}$ & 6 & & \\
\hline & gardeners: rākere & 1 & & \\
\hline Sailors & bōt swein, coks wain & 2 & 2 & 3 \\
\hline \multirow[t]{2}{*}{ Intellectuals } & writers, translators: drauere & 1 & 2 & 3 \\
\hline & physicians: clipper & 1 & & \\
\hline \multirow{2}{*}{$\begin{array}{l}\text { Artists, } \\
\text { entertainers }\end{array}$} & artists: carver, clipper & 2 & 3 & 5 \\
\hline & entertainers: skippere & 1 & & \\
\hline \multirow[t]{4}{*}{ Officials } & lawyers: hei ward, lauiere & 2 & 6 & 9 \\
\hline & messengers: rennere & 1 & & \\
\hline & watchmen: wāke-man, wākere & 2 & & \\
\hline & executioners: slaughter-man & 1 & & \\
\hline \multirow[t]{2}{*}{$\begin{array}{l}\text { Domestic } \\
\text { servants }\end{array}$} & $\begin{array}{l}\text { courtiers, employees of estates and servants: fouere, } \\
\text { găng ffermour, kervere, rākere }\end{array}$ & 4 & 8 & 12 \\
\hline & $\begin{array}{l}\text { carriers, loaders and carters: drauere, feriere, feri-man, } \\
\text { wine drauere }\end{array}$ & 4 & & \\
\hline Traders & $\begin{array}{l}\text { merchants: bagger, hattere, } \quad \text { iren-mōngere, ripiere } \\
\text { silk(e womman, skinnere }\end{array}$ & 6 & 6 & 9 \\
\hline Total number & & & 6 & 100 \\
\hline
\end{tabular}


Loan-blends of this functional group belong to eight semantic subgroups: the names of artisans constitute the core (42\%); the semi-periphery of the group is formed by the names of graziers and farmers (17\%); the periphery of the group is formed by the names of domestic servants (12\%), traders $(9 \%)$, officials $(9 \%)$, the names of artists and entertainers (5\%), intellectuals (3\%) and sailors (3\%).

\subsection{Semantic grouping of Middle English loan-blends which only fulfil the function of identification}

Middle English occupational terms with Scandinavian word stems which are loan-blends that only fulfilled the function of identification as proper names are 96 in number and constitute $13 \%$ of the total number of Middle English loan-blends (their 761 graphic variants were used 904 times in the lexicographic sources). We distribute them within the following semantic subgroups the semantic rows of synonyms.

\subsubsection{Semantic subgroup of the names of artisans}

\subsubsection{Names of textile workers}

a) names of weavers and spinners are the following: *silk(e man 'one who works with silk' MED (silk(e [OE seoluc, seolc, sioloc; also cp. ON: cp. OI silki] 'silk fiber or thread' 1300 MED): Silkman 1371, 1374-5, 1397; *silk(e swōn (in surnames - MED) (silk(e [OE seoluc, seolc, sioloc; also cp. ON: cp. OI silki] 'silk fiber or thread' $1300 \mathrm{MED}$, swōn [OE swān]'a laborer; a male servant' $1150 \mathrm{MED}$ ): Silkeswone 1201; * silk throustere 'one who makes raw silk into silk thread, a silk-thrower' MED (silk(e OE seoluc, seolc, sioloc; also cp. ON: cp. OI silki] 'silk fiber or thread' $1300 \mathrm{MED}$, throuster < throuen v. [OE prāwan] 'a female maker of raw silk or silk thread, one who twists silk fibers into raw silk or raw silk into thread' $1455 \mathrm{MED})$ : sylkthrowster 1423; *silk(e wif 'a woman who spins or sews silk, a seamstress' MED (silk(e [OE seoluc, seolc, sioloc; also cp. ON: cp. OI silki] 'silk fiber or thread' 1300 $\mathrm{MED}$, wif $[\mathrm{OE}]$ 'a human biological female, a woman', viz. silk(e womman 'a woman who spins or sews silk, a seamstress' 1440 MED, 'a woman engaged in the manufacture, use or sale of silk' 1440 NED): Selkwyf 1348;

b) names of dyers are the following: *maderer(e (in surnames - MED), 'dyer with or seller of madder' DBS (mader(e [OE mad (e)re, \& ON (cp. OI maðra)] 'the dye-stuff made from the roots of the plant Rubia tinctorum; a name given to dyes or dyestuffs other than Rubia tinctorum' 1425 MED): Maderere 1317, Madrer 1333; *mader-man (in surnames - MED, 'dyer with or seller of madder' DBS (mader(e [OE mad(e)re \& ON (cp. OI maðra)] 'the dye-stuff made from the roots of the plant Rubia tinctorum; a name given to dyes or dyestuffs other than Rubia tinctorum' 1425 MED, viz. madder-dye, -dyeing, grinder, -miller NED): Maderman 1293; *stepere 'one who steeps; one who carries out the operation of steeping flax, wool, etc.' 1611 NED (stẹpen [*OEE (cp. stēap, stēop 'a stoup, drinking vessel' \& OI steypa 'to pour out')] 'to soak (sth.) in liquid, steep' 1325 MED): Stepere 1327, Stupere 1327.

\subsubsection{Names of tailors and sewers}

Names of tailors and sewers are the following: *hat liner '?one who lines hats' MED (hat [OE hat \& ON; cp. OI höttr] 'an outer head covering (often worn over a hood or a cap), a hat' 1225 MED, *liner < linen v. [< line n. [OE līn] 'to line (clothes, a garment)'): Hatlynere 1325; *hat maker 'a maker of hats' MED (hat [OE hat \& ON; cp. OI höttr] 'an outer head covering (often worn over a hood or a cap), a hat' 1225 MED): hatmaker 1400, 1427-8; *silk(e man 'one who works with silk' MED (silk(e [OE seoluc, seolc, sioloc; also cp. ON: cp. OI silki] 'silken cloth, silk; silken clothing; also, a silken garment' 1200 MED; 'silk embroidery' 1400 MED): Silkman 1371, 1374-5, 1397; *silk(e swōn (in surnames - MED) (silk(e [OE seoluc, seolc, sioloc; also cp. ON: cp. OI silki] 'silken cloth, silk; silken clothing; also, a silken garment' 1200 MED; 'silk embroidery' 1400 MED, swōn [OE swān]'a laborer; a male servant' 1150 MED): Silkeswone 1201; *silk(e wif 'a woman who spins or sews silk, a seamstress' MED (silk(e [OE seoluc, seolc, sioloc; also cp. ON: cp. OI silki] 'silken cloth, silk; silken clothing; also, a silken garment' $1200 \mathrm{MED}$; 'silk embroidery' $1400 \mathrm{MED}$, wîf [OE] 'a human biological female, a woman', viz. silk(e womman 'a woman who spins or sews silk, a seamstress' 1440 MED, 'a woman engaged in the manufacture, use or sale of silk' 1440 NED): Selkwyf 1348. 


\subsubsection{Names of skin-processing workers}

a) names of skinners are the following: *grei tauier 'one who taws skins or hides gray' MED (grei [OE (cp. grāe, grēg adj.) \& ON (cp. OI grār \& LOE grā-scinnen) 'a gray fur; prob. the fur of the back of the Russian gray squirrel in winter' $1175 \mathrm{MED}$, tauier [< tauen v. [OE tāwian] 'one who prepares animal skins or hides for use by dressing, curing, or treating them, a tawer' 1320 MED): greytawyere 1381; *skin wassere (in surnames - MED) (skin [ON (cp. OI skinn) \& OE scinn (from ON)] 'the external covering of an animal's body, sometimes including the fur' 1395 MED; *washere < washen $\mathrm{v}$. [OE wascan, wacsan, waxan, waxsan] 'to remove (a stain) by washing' $1200 \mathrm{MED}$ ): Skynwassere 1281;

b) names of artisans engaged in sewing of leather goods are the following: *bagger, bağğer 'a maker of bags or pouches, or a hawker'(in names) MED (bagge [ON, cp. OI baggi; cp. also OF bague (from Gmc.) \& AL bag(g)a] 'a bag or sack, traveling bag, wallet, satchel, pouch' 1200 MED): Bagger 1246, Baggere 1297, Bagere 1308, Baghiar 1313, Badger 1324, 1346, Baghar' 1329, Badgare 1332, Baggare 1333, Baghere 1348; *bagge-man 'a maker of pouches and wallets' MED (bagge [ON, cp. OI baggi; cp. also OF bague (from Gmc.) \& AL bag $(g) a$ ] 'a bag or sack, traveling bag, wallet, satchel, pouch' 1200 MED): bagman 1329, Bageman 1377, Bagman 1474-5; *glōvers 'a female glove maker' MED (glōver 'one who makes or sells gloves; a member of a glovers' guild' 1364 MED, 1400 NED, glōve [OE glōf \& ON; cp. OI glófi] 'a glove; one of a pair of gloves; a glove or gauntlet used for armor; one of a pair of gauntlets' $1200 \mathrm{MED}$ ): Gloveres 1327; *thonger 'a maker of thongs' DBS (thong [OE pwang, pwong, (A) pwang, Juencg; cp. OI pvengr] 'a strip cut from a piece of leather' $1200 \mathrm{MED}$ ): Thonger 1428.

\subsubsection{Names of artisans engaged in metal mining and metalworking}

1) names of metal-makers (smelters and founders) are the following: *is blouere (in surnames MED) (ìren (is) [OE ìren \& issern, ìsen \& ON; cp. OI jārn, ONorw. jarn, OSwed. iarn, Dan. jern] 'iron, as ore, metal, or commodity' $1200 \mathrm{MED}$, blouere [OE blāwere] 'a bellows blower (in a foundry)' 1351 MED): Isblowere 1303; *iren brenner '?one who works at smelting iron' MED (ìren [OE ìren \& ìsern, isen \& ON; cp. OI jārn, ONorw. jarn, OSwed. iarn, Dan. jern] 'iron, as ore, metal, or commodity' 1200 MED, brennere 'one who makes bricks, etc. by using fire' 1280 MED < brennen v. [ON, cp. OI brenna] 'to treat (sth.) with fire or heat' 1385 MED): Irynbrenner 1430; *iren man (in surnames - MED) (ìren [OE ìren \& ìsern, ìsen \& ON; cp. OI jārn, ONorw. jarn, OSwed. iarn, Dan. jern] 'iron, as ore, metal, or commodity' $1200 \mathrm{MED}$, viz. iren heter 'one who works the bellows or tends the furnace for smelting iron' 1425 MED): yreneman 1327; *silver brennere (in surnames - MED) (silver [OE seolfor, seolfer, siolofr, sylfor] 'the metal silver; also, silver ore' $1150 \mathrm{MED}$, brennere 'one who makes bricks, etc. by using fire' $1280 \mathrm{MED}$ < brennen v. [ON, cp. OI brenna] 'to treat (sth.) with fire or heat' $1385 \mathrm{MED}$ ): Silverberner 1279;

2) names of workers engaged in ironmongery:

a) names of blacksmiths are the following: *iren smith 'a blacksmith, an ironworker' MED (îren [OE ìren \& isern, ìsen \& ON; cp. OI jārn, ONorw. jarn, OSwed. iaern, Dan. jern] 'iron, as ore, metal, or commodity' $1200 \mathrm{MED}$, smith [OE smip] 'a blacksmith, an ironworker; a farrier; a worker in various metals'): irensmyth 1327 ;

b) names of workers who make household utensils, tools, handicrafts are the following: * $k n i \bar{f}$-smith 'a cutler', only as surname - MED (knïf [LOE $(<\mathrm{ON})$ cnïf \& ON; cp. OI knïfr] 'a knife; a dagger or sheath knife carried or worn on the person; a knife as a weapon [usually distinguished from sword]' 1200 MED, smith [OE smib] 'a blacksmith, an ironworker; a farrier; a worker in various metals'): Knifsmith 1246-89, Cnyfsmith 1255, Knysmyt 1284, Knyfsmith 1284, Knyfsmith 1285, Knyfsmyth 1310, Knysmyt 1326, Knyfsmyth 1347; *stithì(e makere MED (stithī(e [ON: cp. OI steði, (gen. \& in cpds.) steðja] 'an anvil' $1284 \mathrm{MED})$ : stethymaker 1413;

c) names of workers who make needles, wires, buckles etc. are the following: *brod $\sim$ smith 'a maker of goads, ?a maker of nails' MED ( $\operatorname{rrod}[\mathrm{ON}$; cp. OI broddr] 'a sprout, a shoot; a pointed instrument, 
a goad; a nail' 1200 MED, smith ([OE smip] 'a blacksmith, an ironworker; a farrier; a worker in various metals'): bradsmyth 1455; *gadder '?a maker of goads, '?one who casts metal bars' MED ( gad(de [ON; cp. OI gaddr] 'a sharp-pointed metal spike' 1400 MED; 'a sharp-pointed stick used for driving oxen etc.; a goad' 1300 MED; 'a metal bar or rod; an ingot of metal' 1250 MED; 'a metal rod used for measuring land' 1440 MED): Gadder 1285, 1324;

d) names of gunsmiths are the following:*arwe makere MED 'a maker of iron arrow-heads' 1400 NED (viz. arwe smith MED (arwe [OE ar(e)wan; cp. OI ör, örvar] 'an arrow' 1200 MED, māker(e (< māken [OE macian] 'a maker, manufacturer' $1347 \mathrm{MED})$ : Aruwemakiere 1305; *gǒnne maister '?a master gusmith' MED (gǒnne [prob. ON; cp. OI gunnr 'battle'] 'a siege engine that casts missiles; ballista, mangonel, trebuchet; also, a ram; a cannon'1339 MED, maister [OF maistre, mestre, mastre \& $\mathrm{OE}$ magister, magester, from L] 'a master tradesman or master craftsman, one qualified to ply his craft on his own account and teach apprentices' 1250 MED): Gunnemeyster 1423.

\subsubsection{Names of artisans involved in woodworking and wooden products manufacturing}

The names of artisans involved in woodworking and wooden products manufacturing are the following: *benkere 'one who makes benches' MED (benk [ON, cp. OI bekkr; Dan. Swed. bänk] 'a bench, a seat; esp., a long, backless seat' 1200 MED): Benkere 1332; *cart-man 'a carter' MED (cart [OE \& ON; cp. WS crat \& OI kartr] 'a cart, a wagon' 1200 MED; 'a cartload' 1400 MED; 'a coach or carriage' 1150 MED): Cartman $1269 ;{ }^{*}$ clubber 'one who makes staffs or clubs' MED (club(be [ON; cp. OI klubba] 'a club or cudgel' 1200 MED; 'a bat' 1500 MED); Clober 1199, Clobbere 1203, Clubber 1301, Clubbere 1316; *fleke maker 'a maker of hurdles' MED (flekke [cp. OI fleki, flaki] 'a frame interwoven with bars and wattles, a hurdle' 1323 MED): Flekmaker 1319;*fleke-man 'a maker of hurdles' MED (fleke [cp. OI fleki, flaki] 'a frame interwoven with bars and wattles, a hurdle' 1323 MED): Flekeman 1292, 1330; *fleke winder 'a maker of hurdles' MED (flēke [cp. OI fleki, flaki] 'a frame interwoven with bars and wattles, a hurdle' 1323 MED, windere [OE wīnden] 'one who turns something' 1432 MED): Flekewynder 1327; *hafter' 'a maker of hafts or handles' MED, 1598 NED (haften [haft n.] 'to provide (a weapon, tool, etc.) with a handle; ?also, make handles' 1440 MED, haft $\mathrm{n}$. [OE \& ON (cp. OI hepti)] 'the handle of a weapon, tool, surgical instrument, etc.; hilt of a sword, knife, dagger, etc.; helve of an ax; 1so, staff of a flag' 1333 MED): Hafter 1275, 1363, Haftere 1290, 1300-1, Heftere 1311, haftere 1317; *lathe-man 'brass-finisher employed in turning at the lathe' 1893 NED (latthe [?ON; cp. OI hlað 'stack'] 'the movable batten of a handloom' 1450 MED; 'some kind of supporting frame or scaffold' 1476 MED; 'a device used by coopers, ?a turning lathe' 1310 MED): Latheman 1278; *spōnman (in surnames - MED) (viz. spọner (e 'one who makes shingles or spoons' $1390 \mathrm{MED}$, 'one who makes spoons' 1515 NED; spọ̄n makere 'one who makes roof shingles or spoons' 1429-30 MED) (spōn [OE spōn; also cp. ON: cp. OI spānn, spōnn] 'a chip or slip of wood, a sliver, splinter' 1300 MED; 'a roofing shingle; a narrow slat of wood' 1310 MED; 'a spoon' 1350 MED): Sponman 1327.

\subsubsection{Names of artisans involved in the processing of stone}

Names of artisans involved in woodworking and wooden products manufacturing are the following: *quệrn(e betere '?one who carves millstones' MED (quệrn(e [OE cweorn \& ON (cp. OI kuern)] 'a small mill for grinding grain, pepper, mustard, etc.; a hand mill, quern' $1300 \mathrm{MED}$; 'one of the pair of stones forming such a mill, a millstone' $1225 \mathrm{MED}$; bèter [OE bēatere] 'one who grinds spices; one who beats cloth, a fuller; a metal-worker (a gold , led ) $1200 \mathrm{MED}$ ): quernbetere 1277; *quệrn(e biler '?one who carves millstones' MED (quệrn(e [OE cweorn \& ON (cp. OI kuern)] a small mill for grinding grain, pepper, mustard, etc.; a hand mill, quern' $1300 \mathrm{MED}$; 'one of the pair of stones forming such a mill, a millstone' $1225 \mathrm{MED}$; *biler < bilen $\mathrm{v}$. [< bile n. [OE] 'beak, mouth'] 'to strike with the beak, jab, peck' 1398 MED): whernebiller 1390; *quệrn(e pekker '?one who carves millstones' MED (in surnames - MED) (quẹ̆rn(e [OE cweorn \& ON (cp. OI kuern)] a small mill for grinding grain, pepper, mustard, etc.; a hand mill, quern' 1300 MED; 'one of the pair of stones forming such a mill, a millstone' 1225 MED; *pekker < pekken v. [cp. piken, v. \& MLG pekken] 'to pick, pluck, or tear (sth. off of sth.)' $1398 \mathrm{MED}$, pīken v. [OE (cp. pīcung n.) \& ON (cp. OI pikka) 'to work with a pick or other digging implement'] 1300 MED): quernpeckere 1381, Quern-pekker 1381, quernepykker 1441; *quẹ̆rn(e hakkere (quệrn(e [OE cweorn \& ON (cp. OI kuern)] a small mill for grinding grain, 
pepper, mustard, etc.; a hand mill, quern' 1300 MED; 'one of the pair of stones forming such a mill, a millstone' 1225 MED; *hakker(e [cp. hak n. \& hakken v.] 'a hacker, chopper, cutter' 1224 MED): Quernhacker 1312-13.

\subsubsection{Names of construction workers}

a) names of builders are the following: *dammer 'one who builds dams' $\operatorname{MED}$ (dammen [from dam n.] 'to dam (a stream)' 1475 MED, dam n. [prob. ON; cp. OI dam, dammr 'dam' \& Dan 'pond'; but cp. OE demman 'stop up, block'] 'a dam; also, the bank of a stream' 1400 MED): Dammer 1327, Dammar

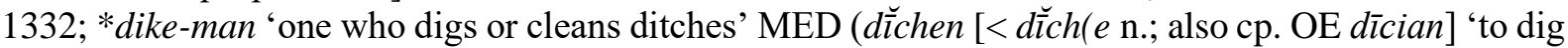
a ditch or ditches' $1300 \mathrm{MED}, d \overline{\bar{l}} \mathrm{ch}(e$ [OE \& ON (OI dīki)] 'an excavated trench; a ditch for fencing an enclosure, marking a boundary, draining water, etc.' 1200 MED; 'a defensive ditch in front of a wall or about a fortified camp, tower, castle , or town' 1175 MED): Dikeman 1206, Dikeman 1227, Dykeman 1301, Dycheman 1301, Dekeman 1327, Dikemon 1332, Dykeman 1428, Dykeman 1474; *dīcher (diker) 'one who digs or cleans out ditches, a ditcher' MED, diker [OE dīcere, dīkere] 'a man who constructs or works at dikes; one who digs ditches or trenches' 1000 NED; 'one who builds enclosure walls of

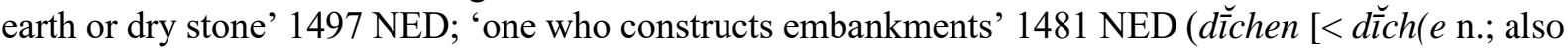

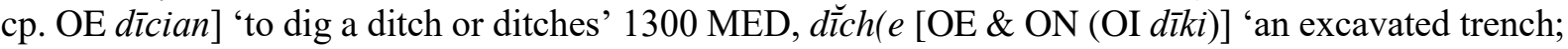
a ditch for fencing an enclosure, marking a boundary, draining water, etc.' 1200 MED; 'a defensive ditch in front of a wall or about a fortified camp, tower, castle, or town' 1175 MED): Dicher 1210,

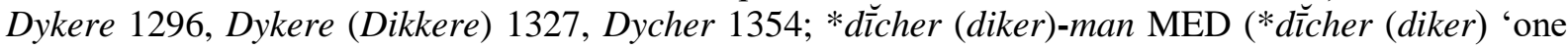
who digs or cleans out ditches, a ditcher' MED, diker [OE dīcere, dìkere] 'a man who constructs or works at dikes; one who digs ditches or trenches' $1000 \mathrm{NED}$; 'one who builds enclosure walls (of earth or dry stone' 1497 NED; 'one who constructs embankments' 1481 NED) (d $\overline{\bar{i}} c h e n$ [< d $\overline{\bar{l}} c h(e$ n.; also cp. OE dīcian] 'to dig a ditch or ditches' $1300 \mathrm{MED}, d \overline{\bar{c}} \mathrm{ch}(e$ [OE \& ON (OI dīki)] 'an excavated trench; a ditch for fencing an enclosure, marking a boundary, draining water, etc.' 1200 MED; 'a defensive ditch in front of a wall or about a fortified camp, tower, castle, or town' 1175 MED): Dykerman 1296; * gẵng shider 'a privy builder' MED (gă̄ng [OE gang, gong \& ON (cp. OI gangr)] 'a privy' 1325 MED; 'a watercourse' $1278 \mathrm{MED},{ }^{*}$ sh $\overline{\bar{l}} d e r<\operatorname{sh} \overline{\bar{l}}$ den v (< shīd(e n. [OE scīd] 'to divide'): Gangishider 1173;

b) names of roofers are the following: *lēd thekere 'a builder of lead roofs; - only as surname' MED (lèd [OE lēad] 'lead, either the metal or the metallic ore', thacchere (<thacchen [OE peccan \& ON: cp. OI pekja]) 'one who covers the roof or walls of a building with thatch or other material' 1312 MED, thache [OE pac, LOE (in place names) tace, tache \& OE paca\& ON (cp. OI pak)] 'sraw, reeds, or similar material used in covering a roof, thatch' $1343 \mathrm{MED}$ ): Ledtheker 1305; *seğğe thekere (seğğe [OE secg] 'sedge, any of several plants of the family Cyperaceae', thacchere ( $<$ thacchen [OE peccan $\&$ ON: cp. OI pekja]) 'one who covers the roof or walls of a building with thatch or other material' 1312 MED: seggethakker 1439 DBS;

c) names of lime-burners and plasterers are the following: *asshe brennere 'maker of potash' MED, 'burner of ashes', 'maker of potash from the ashes of wood, bushes, straw, etc.' DBS (asshe [OE asce, axe \& ON aska] 'ashes of combustible material' 1200 MED, brennere 'one who makes bricks, etc. by using fire' < brennen [ON, cp. OI brenna] 'to treat (sth.) with fire or heat' $1421 \mathrm{MED}$ ): Axbernere 1226, Askebrenner 1278, 1308, Eskebrenner 1278, Asbrinner 1332, Asborner 1332, asshbrynner 1463; *asshe-man (in surnames - MED) (asshe [OE asce, axe \& ON aska] 'ashes of combustible material' 1200 MED): Askeman 1203, Aisshman 1402.

\subsubsection{Names of food-processing workers}

a) names of bakers are the following: *cākier (cāke [ON; cp. Norw. \& Swed. kaka, Dan. kage, ME kẹchel 'little cake' \& OHG kuocho 'cake'.] 'a flat cake or loaf; also, an unbaked cake or loaf' 1225 MED, viz. cakemaker 1591 NED, cakeman 1832 NED): Kakier 1292, Cakyer 1332;

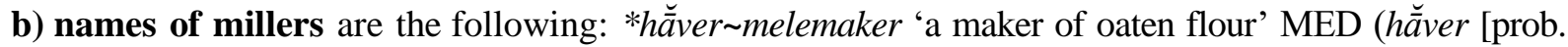
ON; OE *haefera; cp. OHG habaro, MLG häver(e] 'the cereal grain, oats' $1440 \mathrm{MED}$, mēle [OE melu, meolo] 'meal made by grinding grain'): haver-melmaker 1490; 
c) names of butchers are the following: *giller 'one who guts fish or animals' MED ( gille [ON; cp. Norw., Dan. gjalle, Swed. gäl 'gill' \& OI gjölnar '?lips, ?mouth'] 'the gill of a fish' 1325 MED): Giller 1251, Gillare 1313; *slaughterer 'a killer of animals; a butcher' 1648 NED; viz. slaughter-man 'a butcher' 1389 MED (slaughter [ON *slahtr: cp. OI slätr 'butcher's meat'] 'the killing of an animal, usu. for food or sacrifice’ 1350 MED): Slaghterere 1296, Sclaufterer, Slawterer 1327;

d) names of beer brewers and masters of making beverages are the following: *mēd(er 'a maker or seller of mead' DBS (mēd(e [OE; cp. WS medu, a meodo \& ON; cp. OI mjöðr] 'mead; also, drink in general' 1150 MED): Meder 1180, 1332, Medier 1200; *mède maker 'one who makes mead' MED (mēd(e [OE; cp. WS medu, a meodo \& ON; cp. OI mjöðr] 'mead; also, drink in general' $1150 \mathrm{MED})$ : Medemaker 1332.

\subsubsection{Semantic subgroup of names of graziers and farmers}

\subsubsection{Names of graziers (animal husbandry)}

a) names of herdsmen are the following: *lathe-man (in surnames - MED), 'worker at the barn(s)' DBS (läthe [ON; cp. OI hlaða] 'a barn for livestock, grain, etc.; a granary; a storehouse' 1250 MED): Latheman 1278; *muk drauer '?one who hauls manure' MED (viz. mukker '?one who cleans stables, a manure hauler' $1475 \mathrm{MED}, m u k$ n. [ON; cp. OI myki 'dung' \& Norw. dial. mukka 'a heap'] 'animal or human excrement; dung; manure; dirt, filth; sewage; putrescence' $1250 \mathrm{MED}$, drauere $(<$ drauen [OE dragan, cp. OI draga] $1200 \mathrm{MED)}$ 'one who pulls, drags, or transports something' $1450 \mathrm{MED}$ ): mukdragher 1341;

b) names of livestock breeders of cattle are the following: *bōle herd (in surnames - MED) (bōle [ON, cp. OI boli, \& OE *bula] 'a bull' $1200 \mathrm{MED}$, hẹrd(e [OE] 'a herdsman'): Buleherte 1190, Bolherd 1320; *bōle ward (in surnames - MED) (bōle [ON, cp. OI boli \& OE *bula] 'a bull' 1200 MED, ward [OE weard] 'a guard, sentinel; a guardian'): Blleward 1319; *bole-man (in surnames - MED) (bōle [ON, cp. OI boli \& OE *bula] 'a bull' 1200 MED): Bulman 1464; *geld(e-hirde 'a herdsman who tends to the gelded cattle' MED, * geldherd 'one who tended the 'geld' cattle' 1317 NED (geld adj. [ON; cp. OI geldr] viz. geld hors 'a gelding' 1301 MED; geld gris, geld hogge 'a barrow', geld ram, geld shep 'a wether', gelding n. [ON; cp. OI geldingr] 'a gelded horse, gelding' 1387 MED, hẹrrd(e [OE] 'a herdsman'): Geldehyrd 1284, Geildehirde 1298, Geldehirde 1317, Geldhurd 1319; *quie herd 'a herdsman of heifers' MED (quīe hệrd(e (< quīe [ON: cp. OI kvīga] 'a young cow, heifer' 1301 MED): Quihird 1301, Whihird 1332;

c) names of livestock breeders of goats are the following: *bukke swain (in surnames - MED) 'a goatherd' DBS (bukke [OE bucca] 'the adult male goat, he-goat', swein [ON: cp. OI sveinn] 'a retainer, an attendant; a servant' 1200 MED): Bucswayn 1327; *gōter (gater) '?a goatherd; - only as surname' MED (gōt [OE gāt \& ON (cp. OI geit)]) 'a domesticated goat; a male goat' 1200 MED): Gatier 1279, 1332, Geytere 1279, Gater 1279, 1301, Goter 1327, Gotere 1333; *gōt man 'a goatherd' MED (gōt [OE gāt \& ON (cp. OI geit)]) 'a domesticated goat; a male goat' 1200 MED): Gateman 1183, Gaytman 1304, Gooteman 1455, Goteman 1462-3; *gōt herde [OE gät-hyrde] 'a goatherd' MED, 'one who tends goats' 1000 NED (gōt [OE gāt \& ON (cp. OI geit)]) 'a domesticated goat; a male goat' 1200 MED, hẹrrd(e [OE] 'a herdsman'): Gothirde 1229, Gateherde 1275, Gotehird 1285, Gaythirde 1301, Gaytehird 1301, Gaythurd 1304, Gateherde 1327, Gotherde 1332, Gayterd 1466; *gōt grom 'a goatherd' MED ( gōt [OE gāt \& ON (cp. OI geit)]) 'a domesticated goat; a male goat' 1200 MED, grọ̄m [prob. OE * grōm, *grōma] 'an infant boy; a boy; a youth, young man; a man; a male servant, attendant; a retainer' MED; 'a servant who attends to horses' NED): Gotegrom 1335; *gōt carl 'goatherd' DBS, (gōt [OE gāt \& ON (cp. OI geit)]) 'a domesticated goat; a male goat' 1200 MED, carl [ON; cp. OI karl] 'a serf, servant, slave; a freedman; a peasant, a rustic' 1325 MED): Gotenecherl 1183; *kide-man 'a man in charge of the kids' DBS (kide [ON] 'the young of a goat' 1200 MED): Kideman 1221, Kydeman 1275; 
d) names of livestock breeders of horses are the following: *capel-man 'one who looks after horses' DBS (capel [ON; cp. OI kapall (ult. L caballus)] 'a horse or gelding; a warhorse, cart horse, riding horse, etc.' 1300 MED, viz. capel clauer 'horse clawer, stable boy' 1325 MED): Capelman 1327;

e) names of livestock breeders of swine are the following: *galter 'a keeper of swine', as surname MED (galt [ON; cp. OI göltr \& galti] 'a boar; also, a barrow' 1425 MED): Galter 1297, 1498;

f) names of poultry breeders are the following: *gōs swein 'one who tends a flock of geese' MED ( $g \bar{o} s[\mathrm{OE} g \bar{o} s]$ 'a goose of any kind', swein [ON: cp. OI sveinn] 'a retainer, an attendant; a servant' 1200 MED): Goswayn 1245;

2) names of farmers (arable farming) are the following: *berier 'a thresher' MED (berien $\mathrm{v}$. [cp. OI berja 'beat, thrash', \& OE gebered 'crushed, vexed'] 'to beat (sb.), whip' 1250 MED' to thresh (grain)' 1400 MED): Berier 1260, Beryer 1301, Berier 1422; *lathe-man (in surnames - MED), 'worker at the barn(s)' DBS (lāthe [ON; cp. OI hlaða] 'a barn for livestock, grain, etc.; a granary; a storehouse' 1250 MED): Latheman 1278; *plǒugh grọmm (in surnames - MED) (plǒugh [LOE plōg, plōh (from ON) \& ON; cp. OI plogrr, Swed. plog, Dan. plov. As an element in names, plough is most freq. in area of the Danelaw] 'a plow' $1200 \mathrm{MED}$, grọm [prob. OE *grōm, *grōma] 'an infant boy; a boy; a youth, young man; a man; a male servant, attendant; a retainer' MED; 'a servant who attends to horses' NED): Plougrom 1319; *plǒugh hīne (in surnames - MED) (plǒugh [LOE plōg, plōh (from ON) \& ON; cp. OI plōgr, Swed. plog, Dan. plov] 'a plow' $1200 \mathrm{MED}$, hine [OE] 'a servant, member of a household'): Ploghyne 1332; *plǒugh maister (in surnames - MED, plǒugh [LOE plōg, plōh (from ON) \& ON; cp. OI ploggr, Swed. plog, Dan. plov] 'a plow' 1200 MED, maister [OF maistre, mestre, mastre \& OE magister, magester, from L]): Ploghmaystre 1297, Plowthmaister 1434; *stacker 'one who builds up a stack or pile' 1757 NED (stakken (< stak n. [ON: cp. OI stakkr] 'a pile, heap, stack; a stack of hay, grain, wood, etc.' 1300 MED) 'to stack (hay, grain)' 1325MED): Stacker 1264, Stackere 1327.

\subsubsection{Semantic subgroup of names of entertainers}

Names of entertainers are the following: *leyker 'player, actor' DBS (leiken [ON; cp.OI leika, OE läcan] 'to engage in a game or contest, sport; also, trifle; play (with sb. or sth.); take pleasure (in sth.); delight (to do sth.); play (a game with sb.' 1200 MED): Laycar 1274, Leykere 1309, 1327.

\subsubsection{Semantic subgroup of names of officials (lawyers, notaries, etc.)}

Names of officials are the following *benker '?one who sits on the bench, a judge' MED (benk [ON, cp. OI bekkr; Dan. Swed. bänk] 'the bench, on which judges seat' 1338 MED, 'a bench, a seat; a long, backless seat' 1200 MED): Benkere 1332; *marker (e 'notary, writer' DBS (marken [OE \& ON (cp. OI marka \& merkja)] 'to affix a seal to (sth.), confirm' $1382 \mathrm{MED}$, 'to describe (an event, a complaint, etc.) in writing; record (sth.)’ 1382 MED): Marker(e) 1168, 1185, 1260, Merkere 1275, Marker 1297, 1309.

\subsubsection{Semantic subgroup of names of domestic servants}

a) names of courtiers, employees of estates and servants are the following: *bour(e swein DBS (bour (e [OE būr'cottage, chamber'], swein [ON: cp. OI sveinn] 'a retainer, an attendant; a servant' 1200 MED): Bourswain 13..; *hal(l)e swein (in surnames - MED) (hal(le [OE] 'a large private residence, a manorial hall; the large public room in a mansion, palace, ship, etc a chamber, bedroom', swein [ON: cp. OI sveinn] 'a retainer, an attendant; a servant' 1200 MED): Hallesweyn 1327; *muk drauere 'a leader of dung, or, perhaps, a scavenger' DBS; '?one who hauls manure, ?one who cleans streets' MED (muk n. [ON; cp. OI myki 'dung' \& Norw. dial. mukka 'a heap'.] 'animal or human excrement; dung; manure; dirt, filth; sewage; putrescence' $1200 \mathrm{MED}$, drauere 'one who pulls, drags, or transports something' 1450 MED (< drauen [OE dragan, cp. OI draga] 1200 MED): mukdragher 1341; *sweinman (in surnames - MED), swein [ON: cp. OI sveinn] 'a retainer, an attendant; a servant' $1200 \mathrm{MED}$ ): Swaynman 1266;

b) names of carriers, loaders and carters are the following: *cart man 'a carter' MED (cart [OE \& ON; cp. WS crat \& OI kartr] 'a cart, a wagon; a cartload' 1200 MED; 'a coach or carriage' 1150 MED): 
Cartman 1269; *hei-berer 'one who carries or carts hay' MED (hei [OE; cp. OI hey] 'grass cut or mowed and cured (usually as feed for livestock), hay'1225 MED, beerer (e (< bēren v. [OE beran, beoran, beara]) 'one who carries, a bearer, a porter' 1255 MED). Hyberer 1285, Heyberare 1306.

\subsubsection{Semantic subgroup of names of merchants}

Names of merchants are the following: *bọth-man 'keeper of a stall, shopkeeper' MED (bọth [ON; cp. ODan. bōth (Dan. bod) \& OI büð] 'a stall at a market or fair, a merchant's shop' 1200 MED): Bothman 1279, Bouthman 1287, Botheman 1403; *hay-man 'a man who sells hay, a hay-salesman' NED (hei [OE; \& cp. OI hey] 'grass cut or mowed and cured (usually as feed for livestock), hay' $1225 \mathrm{MED}$ ): Hayman 1312, Heyman 1332; *hei monger 'seller of hay' MED; 'seller of hay' DBS (hei [OE; \& cp. OI hey] 'grass cut or mowed and cured (usually as feed for livestock), hay' $1225 \mathrm{MED}$, mōnger(e [OE mangere] 'a merchant, tradesman, dealer'): Heimongere 1230, heymongere 1295, heymonger 1475; *mader(e monger (in surnames - MED) (mader (e [OE mad(e)re, \& ON (cp. OI maðra)] 'the dye-stuff made from the roots of the plant Rubia tinctorum; a name given to dyes or dyestuffs other than Rubia tinctorum' $1425 \mathrm{MED}$, mōnger(e [OE mangere] 'a merchant, tradesman, dealer'): madermanger 1230; *ket mongere 'a seller of meat' MED (viz. Chetmangeregate 1175 MED, Ketmangeregate 1194 MED) (ket [ON; cp. OI kjöt, from *ketwa] 'flesh', mōnger (e [OE mangere] 'a merchant, tradesman, dealer'): Ketmongere 1275; *silk(e man 'one who works with silk' MED (silk(e [OE seoluc, seolc, sioloc; also cp. ON: cp. OI silki] 'silken cloth, silk; silken clothing; also, a silken garment' 1200 MED; 'silk fiber or thread; silk embroidery' 1300 MED): Silkman 1371, 1374-5, 1397; *silk(e wif 'a woman who spins or sews silk, a seamstress' MED (silk(e [OE seoluc, seolc, sioloc; also cp. ON: cp. OI silki] 'silken cloth, silk; silken clothing; also, a silken garment' 1200 MED; 'silk fiber or thread; silk embroidery' 1300 MED, wif $[\mathrm{OE}]$ 'a human biological female, a woman', viz. silk(e womman 'a woman who spins or sews silk, a seamstress' 1440 MED, 'a woman engaged in the manufacture, use or sale of silk' 1440 NED): Selkwyf 1348; *wax mongere (in surnames - MED) (wax [OE weax, wax, wex; cp. OI vax] 'beeswax as used in tapers or other types of candles' 1200 MED, 'beeswax as a valuable commodity or medium of exchange, generally implying eventual use in candles' $1350 \mathrm{MED}$, mōnger(e [OE mangere] 'a merchant, tradesman, dealer'): Waxmongere 1310.

Table 2. Semantic subgroups of Middle English loan-blends with the function of identification

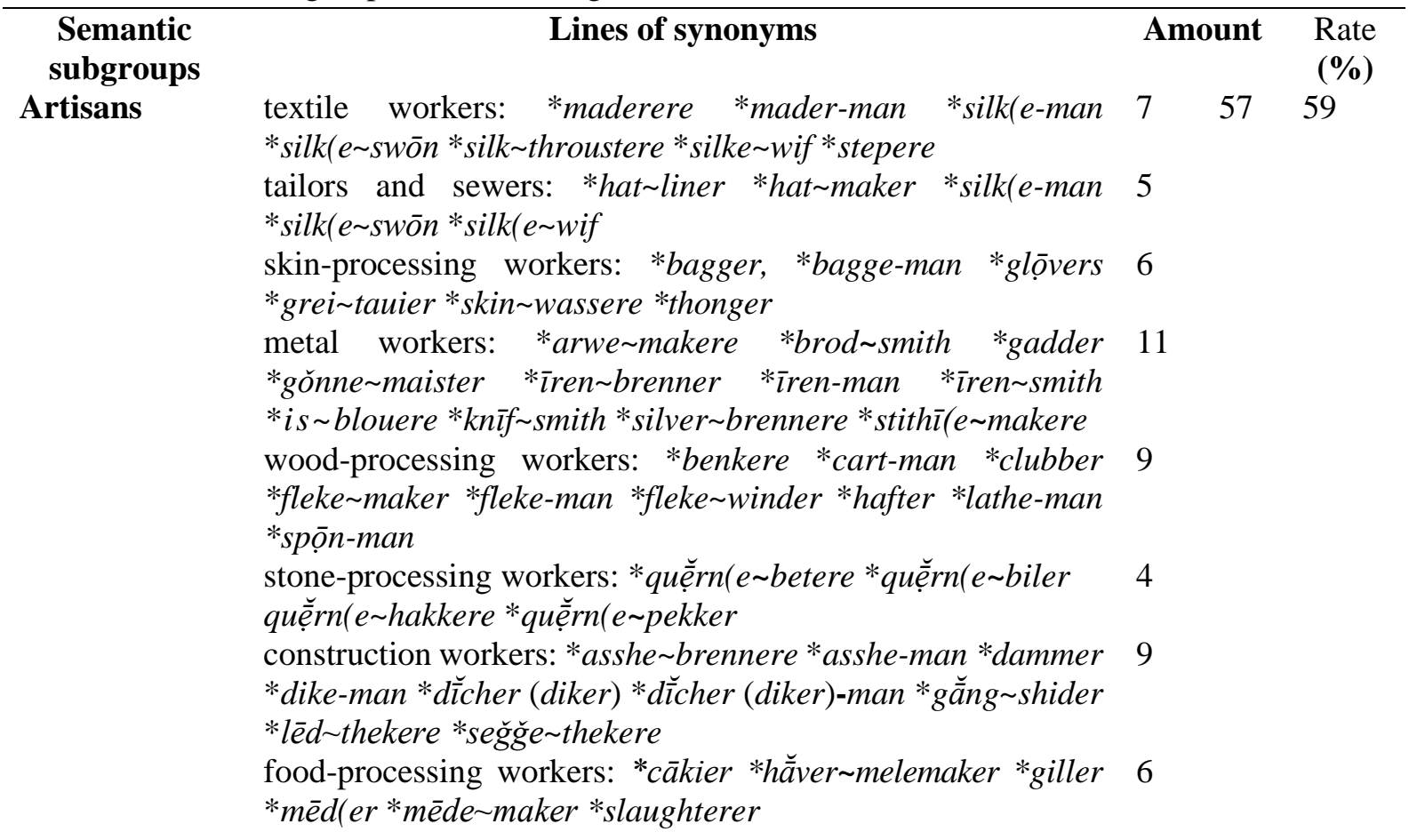




\begin{tabular}{|c|c|c|c|c|}
\hline $\begin{array}{c}\text { Semantic } \\
\text { subgroups }\end{array}$ & Lines of synonyms & & ount & $\begin{array}{l}\text { Rate } \\
(\%)\end{array}$ \\
\hline $\begin{array}{l}\text { Graziers, } \\
\text { farmers }\end{array}$ & $\begin{array}{l}\text { graziers: *bōle } \sim \text { herd *bōle ward *bole-man *bukke swain } \\
\text { *apel-man *geld(e hirde *gōter *gōt-man *gōt } \sim \text { herde } \\
\text { *gōt grom *gōt carl *galter *gōs } \sim \text { swein *kide-man } \\
* \text { muk } \sim \text { drauer *lathe-man *quie } \sim \text { herd } \\
\text { farmers: *berier *lathe-man *plǒugh grōm *plǒugh } \text { *hīne } \\
\text { *plǒugh maister *stacker }\end{array}$ & 17 & 23 & 24 \\
\hline Entertainers & actors: *leyker & 1 & 1 & 1 \\
\hline Officials & lawyers: *benker *markere & 2 & 2 & 2 \\
\hline $\begin{array}{l}\text { Domestic } \\
\text { servants }\end{array}$ & $\begin{array}{l}\text { courtiers, employees of estates and servants: *bour(e swein } \\
* \text { hal(l)e swein *muk drauere *swein-man } \\
\text { carriers, loaders and carters: *cart-man *hei-berer }\end{array}$ & 4 & 6 & 6 \\
\hline Traders & $\begin{array}{l}\text { merchants: *bọth-man *hay-man *hei mongere } \\
\text { *madere mongere *ket mongere *silke-man *silke wif } \\
\text { *wax mongere }\end{array}$ & 8 & 8 & 8 \\
\hline Total number & & 97 & & 100 \\
\hline
\end{tabular}

The loan-blends of this functional group belong to six semantic subgroups: the names of artisans constitute the core (59\%); the semi-periphery of the group is formed by the names of graziers and farmers (24\%), the names of traders (8\%) and the names of domestic servants $(6 \%)$; the periphery of the group is formed by the names of officials $(2 \%)$ and the names of entertainers $(1 \%)$.

\subsection{Semantic grouping of Middle English loan-blends which only fulfil the function of classification}

\subsubsection{Semantic subgroup of names of artisans}

\subsubsection{Names of textile workers (weavers and spinners)}

Names of textile workers are the following: silke makere 'one who works with silk' 1500 MED; silk(e [OE seoluc, seolc, sioloc; also cp. ON: cp. OI silki].

\subsubsection{Names of tailors and sewers}

Names of tailors and sewers are the following: silke makere 'one who works with silk' 1500 MED; silk(e [OE seoluc, seolc, sioloc; also cp. ON: cp. OI silki].

\subsubsection{Names of skin-processing workers (the names of artisans engaged in sewing of leather goods)}

Names of skin-processing workers are the following: bagge maker 1449 MED (bagge [ON, cp. OI baggi; cp. also OF bague (from Gmc) \& AL bag(g)a] 'a bag or sack, with or without its contents; traveling bag, wallet, satchel, pouch').

\subsubsection{Names of artisans engaged in metal mining (smelters and founders)}

Names of skin processing workers are the following: iren heter 'one who works the bellows or tends the furnace for smelting iron; kel-makere' 1425 MED [OE ìren \& ìsern, ìsen \& ON].

\subsubsection{Names of artisans involved in woodworking and wooden products manufacturing}

Names of artisans involved in wooden products manufacturing are the following: leg makere 'a maker of artificial legs' $1500 \mathrm{MED}$ (leg [ON; cp.OI leggr] 'an artificial leg'). 


\subsubsection{Semantic subgroup of names of graziers and farmers}

\subsubsection{Names of graziers (animal husbandry)}

Names of graziers are the following: gelder(e [from gelden] 'one who gelds livestock' 1425 MED (gelden v. [ON; cp. OI gelda] 'to castrate (a male animal); (b) to spay (a sow)').

\subsubsection{Names of farmers (arable farming)}

Names of farmers are the following: plǒugh driver(e 'a plowman' 1475 MED (plǒugh [LOE plōg, plōh (from ON) \& ON]); plǒugh holder(e ‘a plowman' 1425 MED; plǒugh swein 'a plowman' 1296 MED.

\subsubsection{Semantic subgroup of the names of entertainers}

Names of entertainers are the following: knif $\sim$ caster 'one who throws or juggles with knives' 1200 MED (kniff [LOE (from ON) cnif \& ON; cp. OI knïfr]) 'one who throws or juggles with knives'; knif warper 'one who throws or juggles with knives' 1200 MED; lopper [from lōpen] 'a dancer' 1483 MED (loppen v. [ON; cp.OI hlaupa, cp.MDu lopen] 'to jump, leap').

\subsubsection{Semantic subgroup of names of officials (lawyers, notaries, etc.)}

Names of officials are the following: lauistere (lauster) (from laue [LOE lagu]) 'a lawyer' 1376 MED.

\subsubsection{Semantic subgroup of names of domestic servants (esp. names of courtiers, employees of estates and servants)}

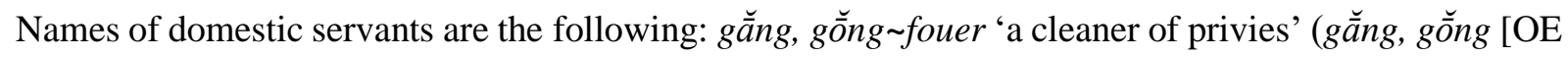
gang, gong \& ON (cp. OI gangr)] 'a privy'; fouer [from fouen] 'a cleaner of privies, etc.' 1411 MED;

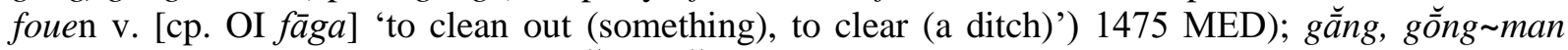
'a cleaner of privies' 1200 MED (gă̄ng, gōng [OE gang, gong \& ON (cp. OI gangr)] 'a privy'); hagis maker 'a maker of haggis' (hagis [haggen] 'a dish of chopped entrails, herbs, etc., boiled in an animal's maw, haggis') 1483 MED; haggen v.[ON; cp. OI höggva]); swalchǒn [?cp. shelchene n., sculiǒun n., \& OIr suail(l 'insignificant'] '?a servant or lowly attendant' 1460 MED.

\subsubsection{Semantic subgroup of names of traders}

\subsubsection{Names of merchants}

Names of merchants are the following: snarler [?from snarlen v.] 'a hawker of goods, esp. of stolen goods' 1398 MED (snāre n [OE snearu \& ON: cp.OI snara] 'a snare for catching birds; also, a trap for other animals'; snarl(e n. [?from snare n. \& -el suf.; also cp. snarlen v.] 'a snare or trap'; snarlen $\mathrm{v}$. [from snarl(e n. or snāren v. \& -el- suf.] 'to trap (sb. or sth.), entangle').

\subsubsection{Names of usurers}

Names of usurers are the following: lèner(e [from lènen v.] 'a lender; a usurer' 1340 MED; 'a giver' 1390 MED (lēnen [OE läenan; also ON; cp. OI lāna]); okerer(e [from okeren v.] 'one who lends money at interest, a usurer; one who otherwise gains excessive returns on investments' 1300 MED; maister okerer (e 'one who puts his money at the disposal of another for the purpose of gain through usury' 1425 MED (okeren v. (from oker [ON; cp.OI okr] 'the lending of money at interest; also lending at exorbitant interest, usury'). 
Table 3. Semantic subgroups of Middle English loan-blends with the function of classification

\begin{tabular}{|c|c|c|c|c|}
\hline \multirow{6}{*}{$\begin{array}{l}\text { Semantic } \\
\text { subgroups } \\
\text { Artisans }\end{array}$} & Lines of synonyms & \multicolumn{2}{|c|}{ Amount } & \multirow{2}{*}{$\begin{array}{l}\text { Rate } \\
(\%) \\
24\end{array}$} \\
\hline & textile workers: silke makere & 1 & 5 & \\
\hline & tailors and sewers: silke makere & 1 & & \\
\hline & skin-processing workers: bagge makere & 1 & & \\
\hline & metal workers: *ìren heter & 1 & & \\
\hline & wood-processing workers: leg makere & 1 & & \\
\hline \multirow{2}{*}{$\begin{array}{l}\text { Graziers and } \\
\text { farmers }\end{array}$} & graziers: geldere & 1 & 4 & 19 \\
\hline & farmers: plǒugh drivere plǒugh holdere plǒugh swein & 3 & & \\
\hline Entertainers & actors: knïf caster knif warper lōper & 3 & 3 & 14 \\
\hline Officials & lawyers: lauistere (lauster) & 1 & 1 & 5 \\
\hline $\begin{array}{l}\text { Domestic } \\
\text { servants }\end{array}$ & 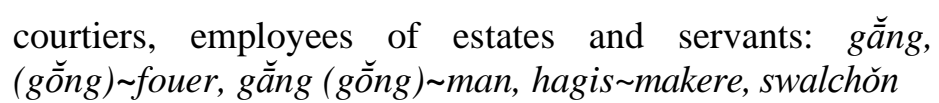 & 4 & 4 & 19 \\
\hline \multirow[t]{2}{*}{ Traders } & merchants: snarler & 1 & 4 & 19 \\
\hline & usurers: lēnere okerere maister okerere & 3 & & \\
\hline Total number & & 21 & & 100 \\
\hline
\end{tabular}

Loan-blends of this functional group belong to six semantic subgroups: the names of artisans constitute the core (24\%); the semi-periphery of the group is formed by the names of graziers and farmers (19\%), traders (19\%) and domestic servants (19\%); the periphery of the group is formed by the names of entertainers (14\%) and officials (5\%).

The ratio of three functional groups is approximately 4:5:1. The most numerous is functional group 2 of Middle English loan-blends only with function of identification (53\%); functional group 1 of Middle English loan-blends with both functions of identification and classification constitutes 36\%, functional group 3 of Middle English loan-blends only with function of classification - 11\%. 
Table 4. Semantic distribution of loan-blends among the functional groups

\begin{tabular}{|c|c|c|c|c|c|}
\hline \multirow[t]{2}{*}{ № } & \multirow[t]{2}{*}{ Semantic subgroups } & \multicolumn{3}{|c|}{ Functional groups } & \multirow[t]{2}{*}{ Amount } \\
\hline & & $\begin{array}{l}\text { Classification/ } \\
\text { identification }\end{array}$ & Identification & Classification & \\
\hline \multirow[t]{3}{*}{1.} & Artisans & 28 & 57 & 5 & 90 \\
\hline & Rate (\%) & 42 & 59 & 24 & 49 \\
\hline & Ratio (\%) & 31 & 63 & 6 & 100 \\
\hline \multirow[t]{3}{*}{2.} & $\begin{array}{l}\text { Graziers, farmers } \\
\text { and gardeners }\end{array}$ & 11 & 23 & 4 & 38 \\
\hline & Rate $(\%)$ & 17 & 24 & 19 & 20 \\
\hline & Ratio (\%) & 29 & 60.5 & 10.5 & 100 \\
\hline \multirow[t]{3}{*}{3.} & Sailors & 2 & - & - & 2 \\
\hline & Rate (\%) & 3 & - & - & 1 \\
\hline & Ratio (\%) & 100 & - & - & 100 \\
\hline \multirow[t]{3}{*}{4.} & Intellectuals & 2 & - & - & 2 \\
\hline & Rate (\%) & 3 & - & - & 1 \\
\hline & Ratio (\%) & 100 & - & - & 100 \\
\hline \multirow[t]{3}{*}{5.} & $\begin{array}{l}\text { Artists } \\
\text { and entertainers }\end{array}$ & 3 & 1 & 3 & 7 \\
\hline & Rate (\%) & 5 & 1 & 14 & 4 \\
\hline & Ratio (\%) & 43 & 14 & 43 & 100 \\
\hline \multirow[t]{3}{*}{6.} & Officials & 6 & 2 & 1 & 9 \\
\hline & Rate (\%) & 9 & 2 & 5 & 5 \\
\hline & Ratio (\%) & 67 & 22 & 11 & 100 \\
\hline \multirow[t]{3}{*}{7.} & Domestic servants & 8 & 6 & 4 & 18 \\
\hline & Rate (\%) & 12 & 6 & 19 & 10 \\
\hline & Ratio (\%) & 45 & 33 & 22 & 100 \\
\hline \multirow[t]{6}{*}{8.} & Traders & 6 & 8 & 4 & 18 \\
\hline & Rate (\%) & 9 & 8 & 19 & 10 \\
\hline & Ratio (\%) & 33 & 45 & 22 & 100 \\
\hline & Total number & 66 & 97 & 21 & 184 \\
\hline & Rate (\%) & 100 & 100 & 100 & 100 \\
\hline & Ratio (\%) & 36 & 53 & 11 & 100 \\
\hline
\end{tabular}

Within each functional group of occupational terms the core of the semantic group is constituted by the names of artisans; the semi-periphery is constituted by the names of graziers, farmers and gardeners, as well as by the names of traders and the names of domestic servants, whereas the names of officials, artists and entertainers constitute the periphery of the semantic group.

Within each semantic subgroup of hybridisms with Scandinavian word stems, the ratio of words with function of identification and those only with function of classification is the following: 1) names of artisans $-94 \%: 6 \%$; 2) names of graziers, farmers and gardeners $-89.5 \%: 10.5 \%$; 3) names of traders - 
$78 \%$ : $22 \%$; 4) names of domestic servants $-78 \%: 22 \%$; 5) names of officials - 89\%: $11 \%$; 6) names of artists and entertainers $-86 \%: 14 \%$; 7) names of intellectuals $-100 \%: 0 \%$; 8) names of sailors $100 \%: 0 \%$. The differences lie in the numbers of words and their percentage, as well as in the existence of the semantic subgroups of the names of intellectuals and the names of sailors within functional group 1.

In total, the most numerous are the names of artisans $(90-49 \%)$, then come the names of graziers, farmers and gardeners $(38-20 \%)$, the names of traders $(18-10 \%)$ and the names of domestic servants $(18-10 \%)$, the names of officials $(9-5 \%)$, the names of artists and entertainers $(7-4 \%)$, the names of intellectuals $(2-1 \%)$ and the names of sailors $(2-1 \%)$.

\subsection{Chronological stratification of Middle English occupational terms that are loan- blends with Scandinavian word stems}

Chronological stratification of the first written records of Middle English loan-blends is presented in Tables 5-9.

Table 5. Chronological stratification of the first written attestation of Middle English loan-blends with Scandinavian word stems (with both the functions of identification and classification):

Data of their first records as common nouns

\begin{tabular}{|c|c|c|c|c|c|}
\hline Century & 12th & 13th & 14th & 15th & Total \\
\hline Total & 1 & 5 & 29 & 31 & 66 \\
\hline Rate $(\%)$ & 1 & 8 & 44 & 47 & 100 \\
\hline
\end{tabular}

Most of the loan-blends are first mentioned as common nouns in the written documents of the 14th century $(44 \%)$ and in the 15th century (47\%); much fewer of them are first attested in the 12th century $(1 \%)$ and in the 13th century (8\%).

Table 6. Chronological stratification of the first written attestation of Middle English loan-blends with Scandinavian word stems (with both the functions of identification and classification): Data of their first records as proper names

\begin{tabular}{lcccccc}
\hline Century & 11th & 12th & 13th & 14th & 15th & Total \\
Total & 3 & 9 & 29 & 23 & 2 & 66 \\
Rate $(\%)$ & 4 & 14 & 44 & 35 & 3 & 100 \\
\hline
\end{tabular}

Most of the loan-blends are first mentioned as proper names in the written documents of the 13th century (44\%) and in the 14th century (35\%); much fewer of them are first attested in the 11th century $(4 \%)$, the 12th century (14\%) and in the 15th century (3\%). The data prove the important fact that Middle English occupational terms with Scandinavian word stems were attested as proper names much earlier than as common nouns, therefore while making the summary we take into account these earlier dates of their first written attestation.

Table 7. Chronological stratification of the first written attestation of Middle English loan-blends with Scandinavian word stems (only with function of identification)

\begin{tabular}{lccccc}
\hline Century & 12th & 13th & 14th & 15th & Total \\
Total & 9 & 39 & 39 & 10 & 97 \\
Rate $(\%)$ & 9.3 & 40.2 & 40.2 & 10.3 & 100 \\
\hline
\end{tabular}


Most of the loan-blends are first mentioned in the written documents of the 13th century (40\%) and in the 14th century (40\%); much fewer of them are first attested in the 12th century (9\%) and in the $15^{\text {th }}$ century $(10 \%)$.

Table 8. Chronological stratification of the first written attestation of Middle English loan-blends with Scandinavian word stems (only with function of classification)

\begin{tabular}{lccccc}
\hline Century & $\mathbf{1 2}^{\text {th }}$ & $\mathbf{1 3 t h}^{\text {th }}$ & $\mathbf{1 4}^{\text {th }}$ & $\mathbf{1 5}^{\text {th }}$ & Total \\
Total & - & 4 & 4 & 13 & 21 \\
Rate $(\%)$ & - & 19 & 19 & 62 & 100 \\
\hline
\end{tabular}

Most of the loan-blends are first mentioned in the written documents of the 15th century (62\%); much fewer of them are first attested in the 13th century (19\%) and in the 14th century (19\%).

Table 9. Chronological data of the first written attestation of three functional groups of Middle English loan-blends with Scandinavian word stems

\begin{tabular}{lcccccc}
\hline Century & 11th & 12th & 13th & 14th & 15th & Total \\
Total & 3 & 18 & 72 & 66 & 25 & 184 \\
Rate $(\%)$ & 2 & 10 & 39 & 36 & 13 & 100 \\
\hline
\end{tabular}

As a result we observe the following items with regard to the chronology of the creation of hybridisms on the lexical basis of Scandinavian borrowings in the Middle English language according to the data of their first written attestation:

a) beginning of the process of loan-word formation in the 11th century (2\%);

b) gradual increase in the process of loan-word formation in the 12th century (10\%);

c) two distinct vertices in the number of loan-blends in the 13th century (39\%) and in the $14^{\text {th }}$ century $(36 \%)$;

d) gradual decline in the process of loan-word formation in the 15th century (13\%).

\section{Conclusions}

1) The study of the functional differentiation of lexical group of Middle English occupational terms with Scandinavian word stems, which is represented by 184 words comprising $24.5 \%$ of all the Middle English hybridisms and $8 \%$ of the total number of 2,417 Middle English occupational terms, lies in a vocabulary distribution according to the functional principle into three groups: a) occupational terms functioning as common nouns and proper names; b) occupational terms functioning exclusively as proper names and c) occupational terms functioning exclusively as common nouns. The ratio of these groups is correspondingly $36 \%: 53 \%: 11 \%$. The predominance of vocabulary with the function of identification (163 words) over that of the function of classification ( 87 words) is in the ratio 2:1, which proves their great popularity and active usage with the purpose of identification of people in the society of the Middle Ages.

As to the functioning of 755 Middle English occupational terms - hybridisms, 53\% of them are words with two kinds of nominative function (identification and classification), $28 \%$ are words with only function of identification and $19 \%$ are words with only function of classification; the predominance of vocabulary with function of identification over that with only function of classification is 4:1 (664 words - to 140 words) (Dobrovolska, 2018, pp. 23); as concerns all the Middle English occupational terms in general (taking native vocabulary, borrowings and hybridisms all together) - the ratio of the functional groups is $43 \%: 40 \%: 17 \%$, and the predominance of vocabulary with function of identification (2,015 words) over that with only function of classification (402 words) is in the ratio 5:1 (Dobrovolska, 2018, pp. 23, 31). Concerning Middle English occupational terms with Scandinavian word stems, the predominance of vocabulary with function of identification (163 words) over that with 
only function of classification (21 words) in the ratio 8:1 proves their greater popularity and more active usage with the purpose of identification of people in the society of the Middle Ages than of other etymological groups, as well as the fact that the function of identification was the major one in this etymological group of loan-blends to a greater extent.

2) As concerns the lexical semantics of loan-blends with Scandinavian word stems, it is distributed among eight subgroups: the names of artisans constitute the core of the semantic group of the names of occupation and office (49\%); the names of graziers, farmers and gardeners $(20 \%)$, the names of traders $(10 \%)$ and the names of domestic servants $(10 \%)$, the names of officials (5\%), the names of artists and entertainers (4\%), the names of intellectuals $(1 \%)$ and the names of sailors $(1 \%)$. These data coincide with the ratio of the semantic groups of all the Middle English occupational terms in general (differing in the rate of the semantic subgroup of the names of graziers and farmers), as far as $42 \%$ of them are the names of artisans, $14 \%$ are the names of traders, $10 \%$ are the names of domestic servants, $10 \%$ are the names of graziers, farmers and gardeners, $7 \%$ are the names of artists and entertainers, $6 \%$ are the names of intellectuals, $7 \%$ are the names of officials, $4 \%$ are the names of sailors and hunters (Dobrovolska, 2016), and the loan-blends among the Middle English occupational terms in particular, as far as $49 \%$ of them are the names of artisans, $11 \%$ are the names of traders, $10 \%$ are the names of domestic servants, $8 \%$ are the names of graziers, farmers and gardeners, $8 \%$ are the names of artists and entertainers, $5 \%$ are the names of intellectuals, $5 \%$ are the names of officials, $4 \%$ are the names of sailors and hunters (Dobrovolska, 2018, p. 24).

Within the six semantic subgroups of all the hybrid Middle English occupational terms, the ratio of the words with function of identification and those with only function of classification is the following: 1) the names of artisans $-92 \%: 8 \%$; 2) the names of grazers, farmers and gardeners $-89 \%: 11 \%$; 3 ) the names of traders $-80 \%: 20$; 4) the names of domestic servants $-71 \%: 29 \%$; 5) the names of officials $-75 \%: 25 \% ; 8$ ) the names of sailors $-79 \%: 21 \%$; in two subgroups, the words not used for the purpose of identification of people prevail (the ratio of the functional groups of the names of artists and entertainers is $48 \%: 52 \%$; and that of the names of intellectuals - 47\%:53\%) (Dobrovolska, 2018, 24-25). The peculiarity of the loan-blends with Scandinavian word stems lies in the predominance of the words with the function of identification in all the semantic subgroups.

3) Data of the personal names give a new precise chronology of the process of formation of the semantic group of the names of occupation and office in the Middle English period. Concerning the chronological stratification of the first written records of the loan-blends, we have combined the data of three functional groups and received a significant increase in the rate of vocabulary that was first attested in the 13th-14th centuries, and the decline of this process in the $15^{\text {th }}$ century. As compared to the results of our previous investigation, these data coincide with the data of the chronological stratification of all the the Middle English occupational terms in general (Dobrovolska, 2016), and all the loan-blends among them in particular (Dobrovolska, 2018, p. 26).

4) On the basis of Middle English personal names, we have revealed 97 loan-blends with Scandinavian word stems, constituting 4\% of all Middle English occupational terms and 13\% of all the loan-blends among them, which only functioned as proper names in the Middle English period, as well as in the next periods of English language development, i.e. our knowledge of their existence in Middle English is only based on the data of proper names - a fact which definitely proves their gnoseologic value for the study of Middle English language development.

\section{Prospective studies}

Taking into consideration all the advantages of the functional approach to the study of vocabulary in its development, we trace the following directions of our further in-depth study of the evolution of the Middle English lexical semantic system:

1. The issues of assimilation of lexical borrowings in Middle English, in particular: 1) their compatibility with other words and affixes; 2) their phraseological activity; 3) the spheres of usage of loan-blends; 4) their degree of distribution in the English language.

2. The issues of synonymy in the Middle English language, in particular: 1) the changes in the semantic structure of Middle English vocabulary, which adapts foreign words; 2) the creation of new thematic areas; 3) the development of series of synonyms; 4) the directions and ways of consolidation 
or differentiation of the meanings of synonyms; 5) the synonymy of borrowings and loan-blends in their relation with English native vocabulary; 6) the chronology of the process of assimilation; 7) the reasons for the displacement of some synonyms by others, in particular the effect of the law of language economy, the semantic and stylistic characteristics of words, the stratification of words in dialects, the process of extinction of the native and borrowed vocabulary, as well as loan-blends; 8) the use of borrowed words and loan-blends in the series of synonym, in particular the significance of the expressed concepts, the degree and completeness of their assimilation in Middle English, as well as the relationship with the native vocabulary in the form of semantic or stylistic differentiation; 9) systematic / nonsystematic potential facts and phenomena of synonymy as realized / unrealized language system capabilities or the consequence of the influence of other languages.

3. The issues of contrastive and comparative studies: 1) the systemic, structural and functional studies of language hierarchy in the field of vocabulary of different languages; 2) the quantitative and qualitative characteristics of loan-blends in the lexical semantic systems of different languages, as well their influence on vocabulary enrichment as compared to the other factors of language development.

\section{List of abbreviations}

AL - Anglo-Latin, DBS - Dictionary of British Surnames, E -English, L - Latin, ME - Middle English, MED - Middle English Dictionary, MLG - Middle Low German, NED - Oxford English Dictionary, OE - Old English, OF - Old French, OHG - Old High German, OI - Old Icelandic, ON - Old Norse, Sc. - Scandinavian

\section{Sources}

Lewis, Robert E. (ed.) et al. 1952-2001. Middle English Dictionary. Ann Arbor: University of Michigan Press. Online edition in Middle English Compendium. McSparran, Frances (ed.) et al. 2000-2018. Ann Arbor: University of Michigan Library. <http://quod.lib.umich.edu/m/middle-englishdictionary/>. Accessed 11 February 2020.

Reaney, Percy Hide. 1966. a Dictionary of British Surnames. London, Great Britain: Routledge and Kegan Paul.

Simpson, John \& Weiner, Edmund (eds). 1989. The Oxford English Dictionary. $2^{\text {nd }}$ ed., 20 vol. Oxford: OUP.

\section{References}

Amosova, N.,1956. Etimologicheskie osnovy slovarnogo sostava sovremennogo angliiskogo iazyka (The etymological foundations of the vocabulary of contemporary English). Moscow. (In Russian).

Arakin, V., 1955. Ocherki po istorii angliiskogo iazyka (Essays on the history of the English language). Moscow. (In Russian).

Baugh, A. C. \& Cable, Th., 1951. a history of the English language. London: Routledge \& Kegan Paul.

Bernatskaia, I., 1995. Onomasiologicheskie aspekty obrazovaniia i funktsionirovaniia naimenovanii lits tvorcheskikh professii $\mathrm{v}$ sovremennom angliiskom iazyke (Onomasiological aspects of the formation and functioning of the names of persons of creative professions in modern English language). (Unpublished PhD Thesis). Sankt-Petersburg. (In Russian).

Björkman, E., 1900-1902. Skandinavian loan-words in Middle English. Halle.

Bradley, H., 1924. The Making of English. New York; London: Macmillan.

Dance, R., 2003. Words Derived from Old Norse in Early Middle English. Studies in the Vocabulary of the South-West Midland Texts: Arizona Center for Medieval and Renaissance Studies.

Derocquigny, J., 1904. a contribution to the study of the French element in English. Lille: Le Bigot Bros.

Davydova, T., 1990. Onomasiologicheskie zakonomernosti obrazovaniia i funktsionirovaniia naimenovanii lits po professii v sovremennom angliiskom iazyke (Onomasiological patterns of formation and functioning of occupational terms in modern English). (Unpublished PhD Thesis). Leningrad. (In Russian).

Dobrovolska, O., 2016 Agentivno-profesiina leksika v istoriï angliis'koï movi: derivatsia i taksonomiia: monografiia (The history of the occupational terms in the English language: derivation and taxonomy: a monograph). Chernivtsi, 624 p. (In Ukrainian) 
Dobrovolska, O., 2018. Rekonstruktsiia rozvytku leksyko-semantychnoi systemy serednoanhliiskoi movy (Na materiali ahentyvno-profesiinoi leksyky 11-15 stolit). (Reconstruction of the Middle English lexical and semantic system evolution (a case study of occupational terms of the 11th-15th centuries): an essay of doctoral thesis). Kyiv: Znannia, 42 p. (In Ukrainian)

Durkin, P., 2014 Borrowed words: a history of loanwords in English. Oxford, 512 p.

Ekwall, E., 1947. Early London personal names. Lund: C.W.K. Gleerup.

El'darov, A., 1984. Ital'ianskie zaimstvovaniia v sovremennom angliiskom iazyke (Italian borrowing in modern English). (Unpublished PhD Thesis). Leningrad. (In Russian).

Emerson, O. F., 1921. The history of the English language. New York; London: Macmillan.

Fransson, G., 1935. Middle English surnames of occupation (1100-1350). London; Lund: C.W.K. Gleerup, William \& Norgate.

Gal'perin, I.R.\& Cherkasskaja, E.B., 1956. Leksikologija anglijskogo jazyka (English Lexicology). Moskow (In Russian).

Greenough, J. B. \& Kittredge, G. L., 1920. Words and their ways in English speech. New York; London: Macmillan.

Groom, B., 1934. a short history of English words. London: Macmillan.

Yartseva, V., 2004. Razvitie natsional'nogo literaturnogo angliiskogo yazyka (Development of the national literary English language). Moskow: Editorial URSS. (In Russian).

Jespersen, O., 1912. The growth and structure of the English language. Leipzig: B.G. Teubner.

Jespersen, O., 1922. Language: Its nature, development and origin. London: Gerge Allen \& Unwin.

Khalilova, M., 1975. Strukturnaia kharakteristika naimenovanii lits po professii v sovremennom angliiskom iazyke (Structural description of occupational terms in contemporary English). (Unpublished PhD Thesis). Moscow. (In Russian).

Kuznetsova, L., 1984. Substantivnoe slovoslozhenie i slovosochetanie v sredneangliiskom iazyke (Substantive word and phrase combination in Middle English). (Unpublished PhD Thesis). Leningrad. (In Russian).

Lindelöff, U. L., 1928. Grundzüge der Geschichte der Englischen Sprache. Leipzig und Berlin.

Liapkova, E., 2006. Vliianie vneshnikh i vnutrennikh faktorov na razvitie nominativnoi sistemy iazyka: na materiale naimenovanii lits po professii (The influence of external and internal factors on the development of the nominative system of language: On the material of occupational terms). (Unpublished PhD Thesis). Cheliabinsk. (In Russian).

Lounsbury, Th. R., 1897. History of the English language. New York: Henry Holt.

McKnight, G. H., 1956. The evolution of the English language: From Chaucer to the twentieth century. New York; London: Dover.

McKnight, G. H. 1969. English words and their background. New York; London: D. Appleton.

Nikitina, L., 2005. Slovoobrazovatel'noe pole suffiksal'nykh sushchestvitel'nykh so znacheniem litsa v sredneangliiskom iazyke (Wordforming field of suffixal nouns denoting persons in Middle English). (Unpublished PhD Thesis). Piatigorsk. (In Russian).

Pedchenko, E., 1956. Rol' skandinavskikh sushchestvitel'nykh v protsesse obogashcheniia slovarnogo sostava natsional'nogo angliiskogo iazyka (na materiale skandinavskikh sushchestvitel'nykh, vydelennykh iz Kenterberiiskikh rasskazov Chossera) (The role of Scandinavian nouns in the process of enriching the vocabulary of the national English language, based on Scandinavian nouns extracted from Chaucer's Canterbury tales). (Unpublished $\mathrm{PhD}$ Thesis). Moscow. (In Russian).

Pons-Sanz, S. M., 2013. The Lexical Effects of Anglo-Scandinavian Linguistic Contact on Old English. Turnhout: Brepols Publishers.

Potter, S., 1964. Language in the modern world. London: Penguin.

Sekirin, V., 1955. Leksicheskaia assimiliatsiia frantsuzskikh slov v angliiskom iazyke (na materiale gruppy sushchestvitel'nykh, zaimstvovannykh v 12-13 vekakh iz oblasti gosudarstvennogo upravleniia i voennogo dela) (Lexical assimilation of French words in English (on the material of a group of nouns borrowed in the $12^{\text {th }}-13^{\text {th }}$ centuries from the field of state administRaten and military affairs). (Unpublished PhD Thesis). Kiev. (In Russian).

Sekirin, V., 1964. Zaimstvovaniia v angliiskom iazyke (Borrowings in the English language). Kiev: Kiev State University. (In Russian).

Serjeantson, M. S., 1935. a History of foreign words in English. London: Routledge \& Kegan Paul. 
Shilova, N., 2006. Formirovanie sistemy proizvodnykh naimenovanii lits po professij v angliiskom iazyke: Sfera remeslenno-promyshlennogo proizvodstva (The formation of a system of derivate occupational terms in modern English: The sphere of craft and industrial production). (Unpublished PhD Thesis). Vladivostok. (In Russian).

Smirnitskij, A., 1956. Leksikologija angliiskogo jazyka (English Lexicology). Moskow. (In Russian). Smith, L. P., 1912. The English language. London: Williams \& Norgate.

Solonovich, T., 1986. Razvitie tematicheskoy gruppy naimenovanij lits po professii v angliyskom yazyke (Unpublished $\mathrm{PhD}$ Thesis) (The development of the thematic group of occupational names in the English language). Minsk. (In Russian).

Thuresson, B., 1950. Middle English occupational terms. Lund: C.W.K. Gleerup.

Weekley, E., 1965. Words ancient and modern. London: John Murray. 